\title{
MARTHA C. NUSSBAUM'UN DUYGU TEORISINDEN HAREKETLE YARGILAMADA EMPATİ VE SEMPATİ KAVRAMLARININ ROLÜ
}

\author{
THE ROLE OF EMPATHY AND SYMPATHY IN JUDGMENT \\ WITH REFERENCE TO MARTHA C. NUSSBAUM'S THEORY OF EMOTION
}

\begin{abstract}
Aydın Furkan KAYNAK*
Makale Bilgi

Gönderi: 27/10/2020

Kabul : 20/03/2021

Anahtar Kelimeler

Empati,

Sempati,

Yargilama,

Martha C. Nussbaum,

Duygu Teorisi.

Özet

https://dai.org/10.21492/inuhfd.816954 ${ }^{\text {oi }}$

Duygular uzun bir süre boyunca yargılamada kullanılmasına karşı çıkılan araçlar olarak görülmüş, hâkimin tarafsızlığına zarar vereceği düşüncesiyle reddedilmişlerdir. Yasa yapma süreçlerini dahi etkileyen duyguların, hâkimin yargılamasında da kendilerine yer bulacağı açıktır. $\mathrm{Bu}$ nedenle yargılamada duyguları reddeden bir anlayışın yerine yargılamada duygulardan nasıl yararlanılabileceği üzerine düşünülmesi gerekir. Çünkü duygular, yargilamada ve hatta sosyal hayatta adaletsizliklerin sebebi olabilir. Martha C. Nussbaum, kendi duygu teorisini geliştirerek duyguların adaletsizliklere nasıl sebep olduklarını göstermiş, geliştirmiş olduğu hümanizm yaklaşımıyla adaletsizliklerin engellenmesi için çalışmıştır. $\mathrm{Bu}$ makalede Martha C. Nussbaum'un duygu teorisinden hareket edilerek mahkemede duyguların öneminden bahsedilecek, ardından empati ve sempati kavramları üzerinde durularak yargılamada bu kavramların edinebileceği rol üzerine tartışılacaktır. Temel iddiamız, empati ve sempatinin hâkimin kendisinin ve yargılamanın taraflarının duygularını anlamada önemli bir araç olacağıdır. Üstelik düşünülenin aksine bu kavramlar, hâkimin tarafsızlığına da gölge düşürmeyecek; tarafsızlığı sağlamada hâkimin elini kuvvetlendirecektir. Empati ve sempati kavramlarının yardımıyla hâkim, yargılamada duyguları alet çantasındaki bir aleti kullanan bir usta gibi kullanacak, duygularının etkisinde değil, duygularının yardımıyla adaleti sağlayacak kararı verecektir.
\end{abstract}

\section{Article Info}

Received: $27 / 10 / 2020$

Accepted: 20/03/2021

\section{Keywords}

Empathy,

Sympathy,

Judgment

Martha C. Nussbaum

Theory of Emotion.

\begin{abstract}
For a long time, emotions were considered as things that were opposed to being used in the judgment and were rejected with the thought that it would harm the judicial impartiality. It is clear that emotions that affect even law-making processes. And it will find their way into the judgment of the judge. For this reason, instead of an understanding that rejects feelings in judgment, it is necessary to consider how emotions can be used in judgment. Because emotions can be the cause of injustice in judgment and even in social life. Martha C. Nussbaum has shown how emotions cause injustice by developing her theory of emotion and worked to prevent injustices with the "Politics of Humanity" that she developed. In this article, the importance of emotions in court will be reviewed, based on Martha C. Nussbaum's theory of emotion. Then empathy and sympathy concepts will be explained and the role these concepts can have in judgment will be discussed. Our main claim is that empathy and sympathy will be an important tool in understanding the feelings of the judge himself/herself and the parties to the judgment. Moreover, contrary to the opposite view, these concepts will not overshadow judicial impartiality. It will strengthen the hand of the judge in ensuring impartiality. With the help of the concepts of empathy and sympathy, the judge will use emotions in the judgment like a craftsman using a tool in a toolbox. And with the help of his/her emotions, the judge can make a fair decision.
\end{abstract}

* Arş. Gör, Selçuk Üniversitesi, Hukuk Fakültesi, Genel Kamu Hukuku Anabilim Dall. 


\section{GİRIȘ}

Bir an için Adalet Tanrıçası'nı gözümüzün önüne getirelim. O, her zaman için gözleri bağlı tasvir edilmiştir. $\mathrm{Bu}$ bağ nedeniyle hakkında karar verdiği kişileri görmeyen tanrıça, böylece tarafsızlı̆̆ını ve objektifliğini korur. Kapalı gözleriyle yargılamayı sürdüren Themis böylece duygularına, kişisel görüşlerine ve ön yargılarına yer vermeden kararını verir, adaleti gerçekleştirir. Hikâye ne kadar güzel olsa da gerçek dünyada işler tam olarak böyle yürümez. Duygular, bir şekilde yargılamada kendilerine yer bulur. İşte bu durumdan yola çıkan makalede öncelikle Martha C. Nussbaum'un duygu teorisi açıklanacak, ardından yargılamada duyguların rolü tartışılmaya çalışılacaktır. Son olarak empati ve sempati kavramlarına dönülerek Nussbaum'un teorisinden hareketle bu kavramların hâkimlerin elinde önemli araçlar olabileceği varsayımının peşine düşülecektir.

\section{MARTHA C. NUSSBAUM'UN DUYGULAR YAKLAŞIMI}

\section{A. Nussbaum'un Yaklaşımının Temelleri}

Martha C. Nussbaum, yakın dönemin en etkili ve önemli düşünürlerinden biridir. Psikoloji, antropoloji, siyaset bilimi, hukuk, felsefe, edebiyat gibi alanları içeren kapsamlı bir program geliştirerek dünyadaki adaletsizlikleri gidermek için aktif bir şekilde çalışmış ve bunu da teorisini pratiğe geçirerek yapmıştır. ${ }^{1}$ Bir eylem planı oluşturan Nussbaum, ilk adım olarak bir duygu teorisi üzerinde çalışmıştır. Nussbaum, ilk olarak eski çağlarda üzerinde sıkça durulan, ancak Aydınlanma ile çoğunlukla irrasyonel olarak görülmeye başlanan duygu kavramı üzerinde durmuş̧tur. ${ }^{2}$ Nussbaum'un, Aristoteles ve Stoacıların duygu teorisinden yola çıkarak geliştirdiği kendi duygu teorisi, sonrasında göreceğimiz "iğrenmenin politikası" ${ }^{3}$ ve "hümanizm anlayışı" ${ }^{4}$ düşüncelerinin dayandığ 1 temeli anlamak açısından önemlidir.

Her şeyden önce Nussbaum'un duygu teorisinin bilişsel ${ }^{5}$ olduğunu söylememiz gerekir. Genel olarak bilişselci teoriler duyguları, otomatik tepkilerden ziyade bireylerin karşıllaştıkları olayları, durumları değerlendirerek bilişsel bir sürecin sonunda sahip oldukları değerlendirmeler olarak görürler ${ }^{6}$. Örneğin yargılama teorisinde duygular, dünyayı deneyimlediğimiz değerlerin, ideallerin, yapıların ve olayların ışığında, kendimiz ve dünyadaki yerimiz hakkında, içinde yaşadığımız yer ve zamana göre bulunduğumuz yargılar olarak görülür. Nussbaum da bu görüşü savunur. Nitekim Nussbaum'un da belirttiği üzere yargılamak ya da değerlendirmek, bireylerin belirli bir deneyimi veya dünyanın belirli bir durumunu kabul ettiklerinde kullandıkları zihinsel yeteneklerdir. Yargılama ya da değerlendirme bu teorideki temel fikirdir. Çünkü burada duygular, bireyin başına gelen ya da maruz kaldığı bir durumdan ziyade aktif olarak içinde bulunduğu bir sürecin sonucu olarak görülürler ${ }^{7}$. Tıpkı Nussbaum gibi diğer yargılama teorisyenleri de yargıların ya da değerlendirmelerin bir duygu için gerekli olduğunu belirtirler. Peki Nussbaum, bu konuyu nasıl ele alır?

Nussbaum, teorisini geliştirirken Yunan Stoacılarıyla Aristoteles'i başlangıç noktası olarak almıştır. Stoacılara göre duygular, kişinin kendi kontrolü dışındaki nesnelere ve hayatındaki diğer kişilere yönelik, kendi gelişimi (flourishing) için büyük önem arz eden değer biçme, değer atfetme ya da değer yargılarıdır ${ }^{8}$. Stoacıların duygu yaklaşımı üç fikri içerir: Bilişsel değerlendirme fikri (the idea of cognitive appraisals or evaluation), kişinin kendi gelişimini sağlaması fikri (the idea of one's own flourishing or one's important goals and projects) ve kişinin kendi kontrolü dişındaki nesnelerin kişinin hedeflerinin unsurları olması fikri (the idea of the salience of external objects as elements in one's own scheme of goals). Duygularımız, kendi gelişimimiz için bu fikirleri dünyadaki olaylar

\footnotetext{
${ }^{1}$ Nussbaum'un Amartya Sen ile geliştirdiği Olanaklar Yaklaşı'mı, temelde bir sosyal adalet kuramıdır. Nussbaum, Hindistan'da bu kuram çerçevesinde çalışmalar yapmıştır. Kuram hakkında daha detaylı bilgi için bkz. GÜVEN, Ebru: "Martha C. Nussbaum'un İnsani Gelişme Olanaklar Yaklaşımı”, Arkhe-Logos Felsefe Dergisi, (4), 2017.

${ }^{2}$ Nussbaum, bugünün dünyasında insanların yalnızca ekonomik faydacılık düşüncesi kapsamında incelenmesine karşı çıkarak ileride göreceğimiz üzere sempatinin reddedilmemesi gerektiğini savunur. NUSSBAUM, Martha C.: Poetic Justice, Beacon Press, 1995, s.XIII.

${ }^{3}$ Nussbaum tarafından yazılan From Disgust To Humanity kitabında "Politics of Disgust" olarak kullanılan bu ifade çevrilirken iğrenmenin politikası ifadesi tercih edilmiştir. NUSSBAUM, Martha: From Disgust To Humanity, Oxford University Press, 2010, s.XVIII.

4 "Politics of Humanity" ifadesi metinde "hümanizm anlayışı" olarak çevrilmiştir. Bkz. Nussbaum, s.50.

5 İngilizcesi "cognitive" olan bu kelime yerine kognitif de kullanılabilir. Bu metinde "bilişsel" kelimesi tercih edilmiş ve bu kavramla duyguların birer tepkiden ziyade, zihinsel bir sürecin ürünleri olduğu anlatılmak istenmiştir.

${ }^{6}$ JOHNSON, Gregory: Theories of Emotion, https://www.iep.utm.edu/emotion/ (Erişim Tarihi: 20.10.2020)

${ }^{7}$ JOHNSON, Theories of Emotion.

${ }^{8}$ NUSSBAUM, Martha C.: Upheavals of Thought: The Intelligence of Emotions, Cambridge University Press, 2001, s.4.
} 
hakkındaki bilgilerimizle birleştirme ve kontrolümüz dışındaki nesnelere ilişkin düşüncelerimizi kaydetme yöntemlerimizdir?.

Stoacıların teorisini özetledikten sonra Nussbaum, bu düşüncenin Batı düşünce tarihini belirli bir süre etkilediğini belirtir. Kendisini, belirli noktalarını takip ettiğinden ötürü Stoacı geleneğin temsilcisi olarak saysa da Stoacı yaklaşımın artık pek kabul görmediğini kabul eder. Batı felsefesinin tarih içerisinde farklı bir yola girdiğine dikkat çeken Nussbaum, Stoacıların duygular hakkındaki görüşlerinin tam karşısında yer alan, duyguları mantıksız ve akıldışı bulan bir söylemin gelişerek egemen konuma geldiğini ifade eder. ${ }^{10}$ Nussbaum'a göre özellikle Aydınlanma Çağı'ndan sonra önem kazanan bu düşünce, akılla duyguları iki zıt kutup kabul ederek duyguları, insanı bir yerden bir yere sürükleyen kuvvetli rüzgarlar ya da dalgalar olarak tasvir etmiş ve duyguların insan rasyonelliğinin bir parçası olmadığını savunmuştur. Nussbaum'un ifadeleriyle bu düşünce insan doğasını ikiye ayırarak duyguları, doğamızın hayvansal yanına ait olarak düşünmekte ve bunu, duyguların zihinsel değil, bedensel olduğu fikrine bağlamaktadır. Nussbaum ise duyguların, elbette diğer zihinsel süreçler gibi bedensel yanlarının bulunduğunu kabul etmekle beraber, duyguların bedensel yanının olmasının onların bilişsel taraflarının olduğunu reddetmek için yeterli bir neden sunamadığını savunmuştur ${ }^{11}$. Yeni bir Stoacı düşünce oluşturmak isteyen Nussbaum gerek Stoacıların birtakım düşüncelerine gerek de Stoacı geleneğe eleştiri getiren yeni yaklaşıma cevaplar geliştirerek kendi teorisini kurar. Böylece Yeni Stoacı duygu teorisini geliştirir.

\section{B. Nussbaum'un Yeni Stoacı Duygu Teorisi}

Nussbaum'un duygu teorisini anlatmaya başlarken söylenmesi gereken en önemli nokta, teorisinin tıpkı Stoacıların teorisi gibi bilişsel bir teori olduğudur. Çünkü ona göre duygular, değer yargılarıdır ${ }^{12}$. Tıpkı jeolojik farklılıkları, bunların sebeplerini ve farklılıkların oluşturduğu manzarayı inceleyen bir gezgin gibi biz de duygularımıza baktığımızda, duygularımızın zihinsel ve sosyal yaşamlarımızın manzarasını şekillendirdiklerini görürüz. Bunun anlamı, duyguların tam olarak kontrol edemediğimiz, bizden bağımsız var olan dünya hakkındaki değerlendirmemizi, muhakememizi şekillendirdikleridir. Bununla beraber, etkilere de açı olmaları meseleyi çetrefilli hale getirir. Bu halleriyle duygular sadece muhakeme mekanizmamıza güç sağlayan, bizden bağımsız araçlar değil; bu muhakemenin oldukça karmaşık parçalarıdır ${ }^{13}$. O halde duyguların ne oldukları, nasıl oluştukları üzerinde durmak gerekir.

Nussbaum duyguların, bireylerin kişisel olarak değer verdikleri bir nesneyi belirli bir şekilde algılamalarının sonucunda oluştuğunu ifade etmiştirr ${ }^{14}$. Buna göre, duygular öncelikle "bir şey" hakkındadır, bir nesneleri vardır. Örneğin Nussbaum'un annesinin hastaneye kaldırılması sırasında yaşadığı korku, keder, umut gibi duyguları annesi hakkındadır ve annesine, annesinin hayatına ilişkindir ${ }^{15}$.

İkinci olarak duygular, içsel ve şahsidirler. Duygular, nesnelerine ait özel bir görme şeklini içerirler ve nesnenin, kişi tarafından nasıl görüldüğüne ve yorumlandığına göre değişkenlik gösterirler. Bu durum, nesneden ziyade nesneyi gören kişiye yönelik bir özelliktir. Gerçekten de korkuyu ümitten, kederi korkudan, nefreti sevgiden ayıran nesnenin bir özelliği değil, o nesnenin kişi tarafından görülme şeklidir. Korkan kişi kendisini ya da sevdiği birisini ciddi bir tehdit altında görürken, bir konu hakkında umutlanan kişi kendisini ya da sevdiği birisini gelecekte gerçekleşmesi muhtemel bir iyi olayın eşiğinde görür ${ }^{16}$. Örneğin bir insan, köpekten korkarken bir diğeri aynı köpeği sevip onunla aynı evi paylaşabilir. Benzer bir şekilde karanlık gecede, tenha bir sokakta karşıdan gelen birini gördüğümüzde hissettiğimiz korku, o kişinin yakın bir arkadaşımız olduğunu anladığımızda rahatlamaya dönüşebilir. Her iki örnekte de nesneler aynı olmasına rağmen, kişilerin nesneleri görme şekilleri, hissedilen duyguyu belirlemiştir.

\footnotetext{
${ }^{9}$ NUSSBAUM, 2001, s.4.

${ }^{10}$ Nussbaum, duygulara karşı ileri sürülen argümanların bir “irrasyonellik” şemsiyesi altında toplanabileceğini ileri sürer. Ona göre, duygulara karşı çıkanların eleştirileri dört başlıkta toplanabilir. Birincisi duyguları muhakeme ile ilgileri olmayan "kör güçler", olarak gören itirazdır. İkincisi, duyguların kişiler tarafından kontrol edilemeyen dış güçlere dayandıkları için kişilerin zayıflığı olarak görülmesi gerektiğini savunur. Üçüncü itiraz, kamusal alana ilişkin tartışmalarda duygulara yer olamayacağını, çünkü duyguların özel yaşama ilişkin olduğunu ileri sürer. Son itiraz ise, duyguları ayrıntılara takılarak sınıf gibi daha büyük sosyal birimlerle yeterince ilgili olmadığı için mahkum eder. NUSSBAUM, 1995, s.56-59.

${ }^{11}$ NUSSBAUM, 2001, s.25.

${ }^{12}$ NUSSBAUM, 2001, s.19.

${ }^{13}$ NUSSBAUM, 2001, s.26-27.

${ }^{14}$ NUSSBAUM, 2001, s.26-31.

${ }^{15}$ NUSSBAUM, 2001, s.27.

${ }^{16}$ NUSSBAUM, 2001, s.27-28.
} 
Nussbaum, üçüncü olarak bir adım daha ileri gider ve duyguların sadece bir nesneyi görmenin yolları olmadığını, aynı zamanda duygu konusu nesneyle ilgili inançları içerdiklerini söyler. Nussbaum'a göre X'i Y olarak görmek için X'in Y olduğuna inanmak gerekir. Tipkı Aristoteles' in de daha önceden belirttiği gibi korkuyu yaşamak için kolay kolay üstesinden gelemeyeceğimiz kötü olayların yaşanmakta olduğuna veya yaşanacağına inanmamız gerekir. Benzer şekilde, öfke sahibi olmak için de bize veya bize yakın bir şey ya da birine önemli bir zarar geldiğine, zarara sebep olan davranışın birisi tarafından kasıtlı olarak yapıldığına inanmamız gerekir. Duyguya ilişkin bu inanç olmadan duygudan bahsedilemez ${ }^{17}$.

O halde özetlersek, duygular insanların kendi yaşamlarıyla, kendi deneyimleriyle ilgili ve ilişkili olan kişilere ya da nesnelere yönelik olduğundan, yakınımızda bulunan, hayatımızla ilgili kişilerin ya da nesnelerin başlarına gelen olaylar hakkında daha yoğun duygular yaşarız. Buna göre duygular, kişinin kendi yaşamıyla doğrudan ilişkili olup temelde kişinin diğerine veya bir nesneye verdiği değerle alakalıdır. Nussbaum'a göre, kişinin bir başkasına veya bir nesneye verdiği değer ne kadar fazla ise bu kişi veya nesneye yönelik hissettiği duygu da o kadar yoğun olacaktır ${ }^{18}$.

Nussbaum'un teorisine göre, değer verdiğimiz kişiler ya da nesnelerle ilgili sürekli yargıda bulunuruz. Bu yargı iki basamaklı bir süreci beraberinde getirir: 1) Değer verdiğimiz bir nesneyle ilgili inanca sahip olma. 2) Bu inancın gerçek olduğunu kabul etme. Örneğin yastayken değer verdiğimiz birini veya bir şeyi bir çeşit kaybetmişiz gibi algılarız. Bu algıyı kabul ettiğimizde yas yaşarız ${ }^{19}$. Değer verdiğimiz bir kişinin hayatının iyi bir yola girdiği inancına sahip olup bu inancı kabul ettiğimizde ise mutluluk duyarız. Ancak bu inançlarımız hatalı olabilir. Nussbaum'un da belirttiği üzere algılarımızı ve inançlarımızı içerdikleri için duygularımız hakkında hata yapabilir, farklı bir inançla hatalı şeyler hissedebiliriz ${ }^{20}$. Örneğin değer verdiğimiz birinin hayatının tehlikede olduğu algısına sahip olup onun için korku duyabiliriz. Ancak aslında o kişinin hayatının tehlikede olmadığını öğrendiğimizde onunla ilgili korkunun hatalı olduğunu anlarız. Yine değer verdiğimiz bir kişinin başarılı olduğuna inandığımızda onun için sevinç duyarız. Ancak duyduğumuz sevinç, o kişinin aslında başarılı olmadığını öğrendiğimizde hatalı olacaktır.

İnançlarımızda hataya düşme ihtimalimizin yanında Nussbaum'un belirttiği diğer ihtimal de duygular üzerine düşünmemiz gerektiğini ortaya koyar. Ona göre, inançların kabul edilmesi her zaman bireyin kendi seçimi olmadığ için de hata ihtimali vardır ${ }^{21}$. İnançlarımız, toplum tarafından inşa edilebilir, düzenlenebilir ve manipüle edilebilir. Böylelikle bilişsel sürecin neticesi olan duygularımız, hatta son derece doğal görünen tepkilerimiz hakkında dahi hataya düşebiliriz. Nussbaum bu noktayı örneklemek için odağını iğrenme/tiksinti hissine çeviriri ${ }^{22}$.

\section{Duyguların Sosyal Temeli ve Projektif İğrenme}

Nussbaum'a göre tiksinme/iğrenme ilk bakışta tutku, yas, öfke gibi toplumsal ilişsiler neticesinde öğrenilen duygular arasında değilmiş gibi görünür. İğrenmenin daha bedensel bir tepki olduğu, dünyayı yorumlamaktan ya da öğrenmekten bağımsız olarak kötü koku, görüntü veya durum karşısında verilen bir tepki olarak yorumlandığını ifade eder. Nussbaum tiksinme/iğrenme uyandıranın, insana zayıf yanını ve ölümlülüğünü hatırlatan şeyler olduğunun altını çizerek güç, hız gibi hayvansal yanlarımızın kabul edilebilir özelliklerinin iğrenme uyandırmadığını; dışkı, ceset, sümüksü şeyler ve benzerlerinin ölümü ve çürümeyi akla getirdiğini, bu yüzden de iğrenmeye, tiksintiye neden olduğunu söyler $^{23}$. Bu haliyle tiksinme/iğrenme son derece doğal bir duygu olarak görünmektedir. Ancak Nussbaum, ilk bakışta gayet doğal ve yüksek bir bilişsel durumun müdahalesi olmaksızın kendiliğinden geliştiği düşünülen iğrenmenin, aslında toplumsal ve bilişsel bir yanının olduğunu, tiksinme/iğrenmenin öğrenilebilir, yani sosyal temelli olduğunu savunur. Bunu, projektif (izdüşümsel, yansıtmalı) tiksinme/iğrenme olarak tanımlayan Nussbaum toplumun, üyelerine sosyal normlar aracılı̆̆ıyla tiksinme/iğrenme duyulacak nesneleri, kişileri ve durumları öğrettiğini belirtir. Ona göre tiksinme/iğrenme, nesneler hakkındaki fikirlerimizle bağlantılıdır. İnsanlar, zehirden arındırıldığı söylenen bir mantarı yeme konusunda sıkıntı yaşamazken, bir hamam böceğini tamamen sterilize edildiği söylense dahi yemezler. Aynı durum, çocukların tuvalet eğitimlerini almaya başlayana kadar

\footnotetext{
${ }^{17}$ NUSSBAUM, 1995, s.61, NUSSBAUM, 2001, s.27-28.

${ }^{18}$ Nussbaum'a göre duygular, insanın belirli bir değer veya değerleri algılamasını sağlar, NUSSBAUM, 1995, s.64. Ayrıca bkz. NUSSBAUM, 2001, s.55-56.

${ }^{19}$ NUSSBAUM, 2001, s.38-39.

${ }^{20}$ NUSSBAUM, 2001, s.28.

${ }^{21}$ NUSSBAUM, 2001, s.38-39.

${ }^{22}$ NUSSBAUM, 2010, s.14.

${ }^{23}$ NUSSBAUM, 2010, s.15.
} 
dışkıdan iğrenmemelerinde de geçerlidir. Bunun sebebi, Nussbaum'a göre, projektif iğrenmenin sosyal normlar tarafindan şekillenmesidir ${ }^{24}$.

$\mathrm{Bu}$ şekillenme, Nussbaum için önemlidir. Duyguların, nesnelerine ait özel bir görme şeklini içerdiklerini ve nesneye dair duyguların, kişi tarafından nasıl görüldüğüne ve yorumlandığına göre değişkenlik gösterdiğini yukarıda belirtmiştik. Nussbaum da gayet doğal, hatta bilişselden ziyade bedensel bir tepki olarak görünen iğrenmenin sosyal normlar tarafından şekillendirilebileceğini ortaya koymuştur. Buna ek olarak sosyal normlar tarafından şekillendirilen duyguların sosyal hayatta olumsuz amaçlar için kullanılabileceğini ve birtakım adaletsizliklere "doğal”' bir gerekçe sunabileceğini açığa çıkarmıştır. İşte Nussbaum'un "iğrenmenin politikası" olarak tek bir çatı altında topladığ davranışların yaptığı da tam olarak budur. Nussbaum bunu, örnekleriyle ortaya koyar.

\section{Hukuki Bir Argüman Olarak İğrenme Politikasının Tarih Boyunca Etkileri}

Bugünlerde eskisi kadar aşikar olmasa da projektif iğrenme, uzun bir dönem boyunca insanların, insan dışı varlıklar olarak görülmelerine ve böylece haklarının, herhangi rasyonel bir gerekçe olmadan hukuk eliyle sınırlandırılmasına, bireylerin hukukun eşit korumasından muaf tutulmasına ve bu durumları sürekli hale getirmek için yapılan damgalamalara sebep olmuş ve insan onuruna karşı olan bütün bu davranışların meşru olduğunu ispatlamak isteyenlerin çok sık başvurduğu bir kaynak olarak kullanılmıştır. İğrenmeyle yasallaştırma arasında kolaylıkla bir bağ kurulamayacağı düşünülse de iğrenme, meşru hatta merkezi bir hukuk kaynağı olarak açıkça savunulmuştur. Nussbaum'un belirttiği üzere, 1950'lerde İngiltere'de Lord Patrick Devlin, toplumun ortalama bireyinin iğrentiyle karşıladığ eylemin kanun koyucu tarafindan, söz konusu eylem üçüncü kişilere zarar vermese bile yasadış1 sayılabileceğini, hatta sayılması gerektiğini savunmuştur ${ }^{25}$. Devlin'e göre eylem, kişiyi doğrudan etkilemese bile onu iğrendiriyor ise hukukun bu eyleme müdahale etmesi gerekir. Aksi bir tutumun, toplumu ahlaken çöküntüye uğratacağını iddia eden Devlin, iddiasını alkolizm ve uyuşturucu bağımlılığıyla mücadeleyle örneklendirmeye çalışır. Devlin'e göre, tıpkı alkolizm ve uyuşturucu bağımlılığıyla gerçekleştirilen mücadele gibi, ahlaka aykırı eylemlerle de mücadele edilmesi gerekir. Aksi halde, toplum parçalanma noktasına gelir. Bu nedenle, Devlin'e göre ahlaka aykırı eylemler karşısındaki tiksinme/iğrenme temelli yasalaştırmalar, toplumun kendisini savunma biçimi olarak görülmelidir ${ }^{26}$.

Nussbaum'a göre Devlin'in bu yaklaşımı, John Stuart Mill'in özgürlük anlayışına ${ }^{27}$ zayıf temelli bir karş1 çıkıştır. Devlin, bireylerin özgürlüğünü kabul etse de toplumun çoğunluğunda güçlü bir iğrenme ve nefret duygusu uyandıran bir eylemin, başka bir nedene ihtiyaç kalmaksızın yasaklanması gerektiğini savunmuştur. Halbuki Mill, eyleme rızası olmayan üçüncü kişileri, rızaları dışında eyleme dahil etmediği sürece yetişkinler arasında, toplumun gözlerinden uzakta gerçekleşen rızaya dayalı eylemlerin yasal düzenlemeye konu edilemeyeceğini ifade etmiştir. Kumar, alkol ve toplum tarafindan aykırı görülen cinsel eylemlerin, her ne kadar ahlaken karşı çıkılabilir olsalar da yalnızca, rıza sonucu bu eylemleri gerçekleştiren bireyleri ilgilendirdiğini, bu nedenle de bu eylemlerin yasal düzenlemelere konu olmasının özgürlüklere müdahale olacağını öne sürmüştür ${ }^{28}$. Devlin ise bu görüşe karşı çıkarak, toplumun yozlaşmasının engellenmesinin daha önemli olduğunu savunmuştur. Ancak Devlin'in gözden kaçırdığı en önemli nokta, toplumların her zaman için iğrenecek-tiksinti duyacak kesimler ve eylemler bulabileceği ve rasyonel hiçbir temel olmadan bu duygularını, kırılgan azınlıkların haklarının kısıtlanması yönünde kullanabilecekleridir. Nitekim Nussbaum da bu noktaya dikkat çekmiştir.

Nussbaum'a göre Devlin'in düşünceleri, iğrenmenin politikasının temelini apaçık bir şekilde göstermektedir. İğrenme-tiksinti, tarih boyunca toplumlar tarafından kırılgan kesimlerin ve azınlıkların damgalanmalarında ve temel haklardan yoksun bırakılmalarında kullanılmıştır. Nussbaum örnek olarak Hint kast sisteminde ve Nazilerin Anti-Semitist yasalarında, toplumun kırılgan bir kesiminin (Hint kast sistemi örneğinde Dalitler) ya da azınlıkların (Nazi döneminde başta Yahudiler olmak üzere diğer azınlıklar) iğrenç bulunduğunu ve hiçbir bilimsel araştırma, rasyonel değerlendirme vs. olmadan kirli, hastalıklı, insan dışı varlıklar olarak görüldüklerini belirtmektedir ${ }^{29}$. İğrenmenin kullanıldığ süreçte çoğunluk, toplumun güçsüz kesimini, insanın doğası gereği iğrenç bulduğu nesnelerle özdeşleştirmiş ve toplumsal gruplar arasındaki eşitsizliği, kırılgan gruplar aleyhine süren hiyerarşiyi

\footnotetext{
${ }^{24}$ NUSSBAUM, 2010, s.16.

${ }^{25}$ NUSSBAUM, 2010, s.XIII. Ayrıca bakınız, HART, H. L. A.: Hukuk, Özgürlük ve Ahlak, Dost Kitabevi Yayınları, Ankara 2014, s.24 vd.

${ }^{26}$ NUSSBAUM, 2010, s.9-10.

${ }^{27}$ Mill’in özgürlük anlayışı için bakınız, MILL, John Stuart: Özgürlük Üstüne ve Seçme Yazılar, Belge Yayınları, İstanbul 2016.

${ }^{28}$ NUSSBAUM, 2010, s.56.

${ }^{29}$ NUSSBAUM, 2010, s.22 vd.
} 
desteklemiştir. Tarih boyunca farklı toplumlarda yaşayan farklı kırılgan gruplar kötü kokma, çürüklük, bedensel veya zihinsel eksiklik gibi niteliklerle etiketlenmiş, buna bağlı olarak hakları ellerinden alınmış ya da hak talepleri geri çevrilmiştir ${ }^{30}$. Hindistan'da Dalitler, Nazi Almanyası'nda ise Yahudiler sürekli olarak bu etiketlere maruz bırakılarak önce insan dışı olarak görülmüş, sonra da hukukun koruma alanının dışında bırakılmışlardır.

Nussbaum, tarihte son olarak eşcinsellerin aynı süreçle karşı karşıya kaldığını ifade ederek bunun en temel sebebini, insanı insan olarak görmeyen iğrenmenin politikası partizanlarının toplumu etkilemesi olarak belirtmiş̧ir. Gerçekten de iğrenmeyi temel alan düşünceler, eşcinsel haklarına karş1 büyük bir kamuoyu oluşturarak Yüksek Mahkemeleri bile etkilemiş ve böylece eşcinsel haklarının kısıtlanmasına neden olmuştur. 2003 yılında Massachusetts Yüksek Mahkemesi ve 2004 yılında Florida Yüksek Mahkemesi eşcinsel haklarıyla ilgili önüne gelen davalarda, onları damgalayan ve onlara nefretle yaklaşan araştırmaları, hiçbir bilimsel veriye dayanmamalarına ve bilimsel otoriteler tarafından standartları sağlamadıkları defalarca belirtilmelerine rağmen, dikkate alarak eşcinsellerin hak taleplerini reddetmiştir ${ }^{31}$. Nussbaum'a göre tıpkı bu örneğin gösterdiği gibi iğrenme duygusu, bir insanın insandan aşağı bir varlık olarak görülmesine neden olur: "İgrenme politikasının partizanları, gay gençlerin arkadaşları ile neler yaptıklarını düşünmeyi bile iğrenç bulurlar. Onların davranışlarının kendilerini kusturmak istediğini söyleyerek eşcinsellerin hayat deneyimlerine sırtların çevirirler. Partizanlara göre, gay gençlerin neler yaptığına sadece bakmak bile, kirletilmek demektir' '32. Bu düşünceden yola çıkan iğrenmenin politikası partizanları uzun yıllar boyunca, eşcinsel bireylerin yaşadıkları zorluklara sırt çevirmiş, bununla da yetinmeyerek bütün vatandaşlara eşit olarak tanınması gereken haklardan eşcinsellerin mahrum bırakılmaları için çaba göstermişlerdir. ABD'de eşcinsel hareketin karşısında yer alanlar, bir adım daha ileri gidip iğrenme ve tiksinti duygularının etkisiyle açık ya da üstü kapalı şekilde eşcinsel bireylerin cinsel yönelimlerinin eyaletler tarafindan cezai yaptırımın konusu yapılmasını talep etmişlerdir. Onlara göre, bireylerin eylemlerinin diğer bireylerde kusma isteği uyandırması, insanların sosyal parya olarak görülerek haklarının kısıtlanması için yeterlidir ${ }^{33}$. Nussbaum'a göre bu düşüncenin destekçileri sadece bu nedenle, eylemi iğrenç buldukları için bireylerin cinsel özgürlüklerini sınırlayan bir anlayışın benimsenmesini savunmuş, hatta mantıksız damgalamalarla toplumda kamuoyu yaratmaya çalışmışlardır. Bu çabaları neticesinde tiksinme/iğrenme duygusu yüksek mahkemeleri etkisi altına almış ve tıpkı daha önce ırk ayrımcılığında olduğu gibi toplumun ortalama bireyinden cinsiyet, cinsel yönelim gibi konularda farklı olan bireyleri görünmez kılınmıştır. Bu görünmezlik, kırılgan gruplardaki bireylerin kırılganlığını gerek sosyal yaşamda gerek de hukuk karşısında daha da artırarak adaletsizliğe neden olmuştur.

Ezcümle eşcinsellere yönelik iğrenme ve tiksinti, bedensel birer tepki olarak görülebilecek duyguların dahi insanları nasıl etkileyebileceğine ilişkin örneklerden yalnızca biridir. Tarih boyunca 1rk, ekonomik durum, cinsiyet temelli iğrenme ve tiksintiyle karşılaşılmış ve aynı süreç işletilerek kırılgan grupların adaletsiz yasalara, uygulamalara maruz kalmalarına neden olunmuştur. Örneğin 19. ve 20. yüzyılda yine iğrenmenin politikası temelli ırk ayrımcılı̆̆ının neden olduğu ayrımcılık, eşitsizlik ve hiyerarşi sebebiyle farklı ırklardan bireylerin evlenmeleri, hatta aynı okullara, aynı sosyal alanlara dahi gitmeleri yasadışı sayılmıştır. Nussbaum, iğrenmenin politikasının temel bir gerçeği görmezden geldiğini, hepimizin aynı türe mensup olduğunu unuttuğunu ve bu nedenle de toplumumuzda yaşayan kırılgan bireylerin kırılganlıklarının devamına neden olarak başlı başına adaletsizlik yarattığını söylemiştir. Bu geçmişte farklı kırılgan kesimlerin hak taleplerinin dinlenmemesine neden olmuş, bugün farklı kesimlerin taleplerinin dinlenmemesine neden olmakta, gelecekte ise bambaşka kesimlerin taleplerinin dinlenmemesine neden olacaktır. Nussbaum, süregelen bu adaletsizliğin önüne geçmek için "hümanizm anlayışı" yaklaşımını geliştirmiştir.

\section{E. Nussbaum'un 'Hümanizm Anlayışı"'}

Nussbaum'un "hümanizm anlayışı" olarak isimlendirdiği yaklaşımının temelinde her insana eşit saygı vardır. Başlangıç insana saygıdır ve insanın kendinde bir amaç olarak kavranmasıdır ${ }^{34}$. Nussbaum öncelikle Antik Yunan ve Aristoteles okuması üzerinden yaşamımızın birçok iyiyi

\footnotetext{
${ }^{30}$ NUSSBAUM, 2010, s.16-21.

${ }^{31}$ NUSSBAUM, Dr. Paul Cameron'ın bilimsel otoriteler tarafından reddedilen çalışmalarına yüksek mahkeme kararlarında atıf yapılmaktan çekinilmediğini belirtirken Cameron'ın bilimsellik kisvesi altında iğrenmenin politikası yanlısı açıklamalar ve yayınlar yaptığının altını çizer. Daha fazla bilgi için bakınız, Nussbaum, 2010, s.7-8.

32 NUSSBAUM, 2010, s.XVII.

${ }^{33}$ NUSSBAUM, 2010, s.XIV.

${ }^{34}$ ERKIZAN, H. Nur Beyaz: "Küresel Politik Liberalizmde (Global Political Liberalism) İnsan ve Eğitim”, Aristoteles'ten Nussbaum'a İnsan içinde, Sentez Yayıncılık, İstanbul 2012, s.150.
} 
içerdiğini belirtir; barınma, beslenme, çeşitli bağlılıklar, dostluklar, politik hayat yaşamımızın özsel bir parçasını oluştururlar ${ }^{35}$. Ancak günümüz etik, özellikle de politik sorunlarımızın birçoğu yukarıda belirtilen ve insanın doğasına, işlevine ve kapasitesine, yaşamımızın en özsel, içsel bileşenlerine odaklanmamaktan kaynaklanır. Bizler duygulara, hayvansal bir doğaya sahibiz. En sevdiğimiz birinin ölümü, hatta sevdiğimiz bir hayvanın ölümü iyi yaşamımızı, mutluluğumuzu etkiler. Ölümlüyüz, haz ve acı duyarız. Diğerlerine bağımlıyız, güleriz, oynarız, akıl yürütürüz. Dolayısıyla bunlar gibi ortak kapasitelerimiz içerisinde işlevimizi gerçekleştirme şansımızın, büyük engellerle karşılaşmama ihtimalimizin, örneğin bir birey olarak bir felsefeci, bir tiyatrocu, bir film yapımcısı olma türünde isteklerimizin ve bunlara dair projelerimizi hayata geçirme imkanımızın diğerleriyle eşit olması gerekir. $\mathrm{Bu}$ isteklerimizin peşinde koşarken projektif iğrenmeden kaynaklı engellemelere maruz bırakılmamalı, hukuki kısıtlamalarla karşılaşmamalıyız. Politik kurumlar, toplumsal ve bireysel alışkanlıklar, bizlere eşit olanaklar vermelidir.

Nussbaum'un belirttiği gibi önemli toplumsal sorunlarımız kesinlikle talihten değil, bizden kaynaklanır ${ }^{36}$. Nussbaum, bu durumla mücadele için tek başına kuralların yeterli olmayacağına, duygu dünyasının da sürece dahil edilmesi gerektiğini ifade eder. İnsanların insanca olanaklarla yaşayabilmeleri için bireylere saygı duyulmasının şart olduğunu savunur. Saygı, insanları geniş bir yelpazedeki insani amaçların peşinde koşan, eşit haklara ve insan onuruna sahip olarak görmeyi gerektirir $^{37}$. Bu düşünceye göre saygının nesnesi, bireylerin eylemleri değil, bizzat bireylerin kendisidir. Madem bütün insanlar eşit yaratılmış ve aynı ortak insani özü taşımaktadırlar, o halde bütün insanlar onur sahibi varlıklar olarak saygı görmeyi hak ederler. Bu minvalde, bireyin eylemlerini onaylamıyor, bu eylemleri iğrenç ya da günah olarak görüyor olabiliriz. Ancak insan onuruna ve eşit haklara sahip bireylerin tercih etme hakkına saygı duymak zorundayı. Nussbaum da insanların bu gizemli dünyada bir anlam arayışı içinde olduğunu ve farklı grupların, arayışlarını farklı şekilde yaptıklarını belirterek diğer grupların yanlış yolda olduğunu düşünsek dahi onlara saygı duymamız gerektiğini belirtir ${ }^{38}$. Ancak bu, Nussbaum'un da kabul ettiği üzere, pek kolay değildir. Her ne kadar bir toplum içinde yaşıyor olsak da başkalarına iğrenerek yaklaşan insanlara, diğer kişilere sayg1 duyması gerektiğini söylemek tek başına saygıyı sağlamayacaktır. İğrenme-tiksinti yaşayan insanlar, diğerlerine saygı göstermek için hazır değillerdir; çünkü diğerlerini gerçekten ve tamamen göremezler. İğrenme, diğer insanları küçümseyerek onları, insan onuruna sahip olmayan hayvanlar veya "şeytanlar" olarak görmeye neden olur. Bu nedenle saygı, her ne kadar öncelikli olsa da tek başına yeterli değildir. Nussbaum'un sevgiye yakın şey olarak tarif ettiği ve bir diğerinin deneyimini anlamaya ilişkin tahayyül etme kapasitesinin de geliştirilmesi gerekir. Çünkü iğrenmenin sebebi, başkasının deneyimini anlamadaki beceriksizlik, diğer bir ifadeyle sempati yoksunluğudur ${ }^{39}$.

Nussbaum için bir insanın insan olarak görülmesi ve saygıya konu olabilmesi, onun deneyiminin, hayatının diğer insanlar tarafından tahayyül edilmeye çalışılmasıyla mümkündür. Bunun için kendini başka kişinin yerine koyarak tahayyül etmek gerekmektedir. Başkalarının gözüyle dünya görülmeye çalışılmalı ve onların hissettikleri deneyimlenmelidir. Nussbaum, iğrenme duygusunun başkasını insan olarak görmeme anlamına geldiğini belirtirken, görmenin ancak tahayyül etme egzersizi yapılarak gerçekleşeceğini belirtmekte ${ }^{40}$, insanlığın kendisini otomatik olarak yabancı olanlara göstermeyeceğini ileri sürmektedir. Kaldı ki insanlar da yabancı olanı görmekte istekli değildir. Tarih boyunca yabancı olanın iğrenilecek, kendisinden tiksinilecek bir şey olarak görülmesi daha sık görülmüştür. Ancak kişinin gözleriyle dünyaya baktığımızı tahayyül edersek, diğer kişiyi bir şey olarak değil, bir kişi olarak görebiliriz ${ }^{41}$. İnsanların yaşamlarında ne gibi sorunlarla karşılaştıklarını, hangi seçimin gerekli olduğunu daha net bir şekilde anladığımızda ve öncelikle bunu anlamak için tahayyül etme kabiliyetimizi ciddi ve sempatik bir şekilde kullandığımızda, insanları da bir şey olarak değil, insan olarak görmeye başlarız.

\footnotetext{
${ }^{35}$ MUTLU, Barış, “Martha Nussbaum'da İyi Yaşam ve Duyguların Yeri’, Current Debates in Philosophy \& Psychology, Vol. 11 içinde, Editör: Bora Erdağı, https://books.google.com.tr/books?id=vNJFDwAAQBAJ\&printsec=frontcover\&hl=tr\#v $=$ onepage \&q\&f=false, $\mathrm{s} .48$ (Erişim Tarihi: 21.10 .2020$)$

${ }^{36}$ MUTLU, s.48.

${ }^{37}$ NUSSBAUM, 2010, s.51.

${ }^{38}$ NUSSBAUM, 2010, s.47-48.

${ }^{39}$ NUSSBAUM, 2010, s.XVII.

${ }^{40}$ Nussbaum, bağ kurucu hayal gücünün geliştirilmesi gereken bir değer olduğunu ifade etmektedir. Ona göre bağ kurucu hayal gücü, kendimizi ve kararlarımızı sürekli başkalarıyla karşılaştırmamızı ve kendimizi bir romandaki karakterle veya bize yakın olmayan ama yaşam öyküsünü hayal ettiğimiz biriyle özdeşleştirmemizi, sadece özdeşleşmekle kalmayıp, kaçılmaz olarak bu hikâyeyi kendi amaçlarımız ve eğilimlerimiz ışığında sorgulamamızı sağlar. NUSSBAUM, Martha C.: "İnsanlığın Hukuk Eğitiminde Geliştirilmesi”, (Çev. Aysima Çalışan - Eray Yağanak) Arkhe-Logos Felsefe Dergisi, (4), 2017, s.140.

${ }^{41}$ UYGUR, Gülriz: Hukukta Adaletsizliği Görmek, Türkiye Felsefe Kurumu, Ankara 2013, s.51.
} 
Bugün, her ne kadar zaman zaman aksini görsek de yukarıda ifade edilen saygının temelinin toplumlarımızın temelinde yer aldığı söylenebilir: Tüm insanlar eşit değerdedir ve bu değer doğal ya da içseldir. Tüm insanlar sadece insanlıkları nedeniyle eşit saygı ve değere sahiptir. Bugünkü modern hukuk sistemleri, her bireyin eşit değere sahip olduğunu kabul etmiştir. Eşit değer, eşit saygı duyulmayı da beraberinde getirmelidir ${ }^{42}$. Nussbaum bunu sağlamak için diğerini insandan daha aşağ 1 gören tiksinme/iğrenme duygusunun karşısına empati ve sempatiyle tahayyül etme kabiliyetini yerleştirir ${ }^{43}$. Peki hukuk sistemleri bu durumu nasıl karşılar? Örneğin bir yargılamaya empati ve sempatinin dahil edilmesi, hâkimden taraflara empati ve sempati duymasının istenmesi kabul edilebilir mi? Eşit değerde olduğu söylenen bireyler, mahkeme salonunda karşılaştıklarında duygulardan bağımsız bir yargılama yapılabilir mi?

\section{DOĞRU DEĞERLENDİRMEDE DUYGULARIN ÖNEMİ VE EMPATİ- SEMPATININ OLANAKLILIĞI}

\section{A. Yargılamada Duyguların Önemi}

" Tıpk kuralların ihmali gibi kişilerin ihmali de canavarlar yaratır", 44.

Bugün dahi pek çok hukuk sisteminde hâkimlerden yargılamada duygularına yer vermemeleri beklenmekte, duygular, gerekçelendirmenin karşısına konularak adaletsizliğin bir sebebi olarak görülmektedir ${ }^{45}$. Duygular, Amerikan Yüksek Mahkemesi tarafindan uzunca bir süre gerekçelendirmenin bir parçası olarak kabul edilmeyerek "kapris" olarak görülmüştür ${ }^{46}$. Hatta, özellikle ceza yargılamalarına rehberlik etmeleri için rasyonel kurallar getirerek yargılamada karşılaşılacak duygusal etkilere karşı kapsamlı bir proje yürütülmüştür ${ }^{47}$.

Yargılamada duygulara yer verilmemesine yönelik düşünceler, özellikle Amerika'da, hukukun üstünlüğü (Rule of Law) anlayışından hareket ederek duyguların meşruiyetini ve rasyonelliğini reddetmişlerdir ${ }^{48}$. İronik bir şekilde reddedilen duyguların kanunlaşan yasaları etkileyebilmesi, bu şekilde hukuk düzenine dahil olabilmesi mümkünken bu yasaları uygulayan mahkemenin duygulardan arındırılması düşüncesi uzunca bir süre yerleşik düşünce olarak varlığını sürdürmüştür ${ }^{49}$. Bu düşünce, formel kurallara uygun olmayan, sezgisel, kişisel ve duyguların tutkulu bir şekilde kullanıldığ kararların verilmesini doğru bulmaz ${ }^{50}$. Hatta bir adım daha ileri giderek duygu eksikliğinin adaletin temel bir niteliği olduğu sonucuna varır, böylece yargılamada duyguların kullanılmasına adaletsizlik etiketini yapıştırır ${ }^{51}$. Bu nedenle hâkimlerden de yargılamayı soğukkanlılıkla yürütmelerini bekler ${ }^{52}$. Samuel Pillsbury bu düşünceye "tarafsızlık efsanesi (myth of dispassion)" der ve bu düşüncenin iki temel kurguya dayandığını belirtir: 1) Yargılamada duyguların mutlaka adaletsizliğe neden olması ve 2) Hâkimlerin mutlaka soğukkanlı olmaları gerektiğ $i^{53}$. Böylelikle Themis'in gözleri bağlı kalır, tarafsızlık ve objektiflik sağlanarak adil karar verilebilir. Peki gerçekten de duyguları yargılamadan dışlayarak adil bir karar verilebilir mi? Duyguların, örneğin aile hukuku gibi alanlarda kabul edildiğini,

\footnotetext{
${ }^{42}$ NUSSBAUM, Martha C., Political Emotions: Why Love Matters for Justice, The Belknap Press of Harvard University Press, England 2013, s.145.

${ }^{43}$ NUSSBAUM, 2010, s.XVII.

44 JOHN NOONAN'dan aktaran HENDERSON, Lynne H., "Legality and Empathy”: Scholarly Works içinde, Paper 870. http://scholars.law.unlv.edu/cgi/viewcontent.cgi?article=1893\&context=facpub, s.1574. (Erișim Tarihi: 21.10.2020)

${ }^{45}$ PILLSBURY, Samuel H., "Emotional Justice: Moralizing the Passions of Criminal Punishment”, Cornell Law Review, Volume 74 içinde, 1989, https://pdfs.semanticscholar.org/433b/de6775a3bfe7a9dd3e7e1005f9b3421c2623.pdf, s.655. (Erişim Tarihi: 20.10.2020) Pillsbury, özellikle ceza yargılamasında, duyguların linç kültürünü tetiklemesinden korkulduğunu, bu nedenle hâkimlerden olaylara soğukkanlılıkla yaklaşmalarının beklendiğini belirtmiştir.

${ }^{46}$ PILLSBURY, s.655. Lisa Flower, İsveç hukuk sisteminde duyguların, rasyonaliteyi yıkan şeyler olarak göründüğünü belirtir. Bkz. FLOWER, Lisa, "Doing Loyalty: Defense Lawyers' Subtle Dramas in Courtroom”, Journal of Contemporary Ethnography içinde, https://lup.lub.lu.se/search/ws/files/13744216/Doing_loyalty_final_draft.pdf, s.3, (Erişim Tarihi: 22.10.2020)

${ }^{47}$ PILLSBURY, s.655.

${ }^{48}$ HENDERSON, s.1575.

${ }^{49}$ HENDERSON, s.1575. Buna ek olarak Lisa Flower da hâkimler nezdinde duyguların hiyerarşik bir düzende olduklarını ve bu düzende üst sıralarda yer alan duyguların yargılamaya dahil edilmelerinin sorun olarak görülmediğini belirtir. FLOWER, Lisa “"The (Un)emotional Law Student", Int. J. Work Organisation and Emotion, 6(3), s.297, https://www.soclaw.lu.se/sites/soclaw.lu.se/files/the-unemotional-law-student_0.pdf (Erişim Tarihi: 22.10.2020)

${ }^{50}$ PILLSBURY, s.655.

${ }^{51}$ LITTLE, Laura, “Adjudication and Emotion", Florida Coustal Law Journal, 3, 2002, p.208. https://ssrn.com/abstract=1367943, (Erişim Tarihi: 22.10.2020)

${ }^{52}$ Flower, objektifliğin hâkim ile taraflar arasında bir mesafe yaratmak amacıyla, duyguların bastırılmasının ise objektifliğin inşa edilmesi için kullanıldığını ifade eder. Ona göre, hâkimler bir “"bir duygu yönetimi stratejisi”' benimsemişlerdir. FLOWER, "The (Un)emotional Law Student", s.299.

${ }^{53}$ PILLSBURY, s.666.
} 
ayrıca herhangi bir değerlendirmenin doğası gereği duygusal bir katılım gerektirmesini düşündüğümüzde bu sorun, iyice içinden çıkılmaz bir hale bürünür ${ }^{54}$.

Günümüzde bu görüşü büyük ölçüde gerçek dış1 bularak reddeden düşünürler vardır ${ }^{55} . \mathrm{Bu}$ düşünürlere göre artık hâkimlerin büyük bir çoğunluğunun kararlarını kişisel ve duygusal bir bakış açısıyla verdiğini kabul etmemenin bir gerçeği görmezden gelmek olduğunu söyleyebiliriz. Hatta mahkemede duyguların yönetimi üzerinde çalışmalar da yapılmaktadır ${ }^{56}$. Bu nedenle duyguların yargılamadaki yerini belirtmek, cılız bir çaba olmaktan tutarlı bir girişim haline gelmiştir ${ }^{57}$.

Bilişsel bir sürecin sonucu olan duygular, ne kadar engellenmeye çalışılsa da yargılamada kendilerine yer bulurlar. Çünkü insan doğası gereği duygusal tepkiler verii ${ }^{58}$. Hâkimler de duygusal tepkiler verir. $\mathrm{Bu}$ nedenle sorunu yargılamada duygulara yer verip vermemeden başka bir düzleme taşımamız gerekir. Tartışmamız gereken, duygulara yargılamada ne kadar önem verilmesi gerektiği olmalıdır.

Kendilerine yargılamada yer bulan duyguların, yargılamayı olumsuz yönde etkileme riskinin bulunduğu açıktır ${ }^{59}$. Hâkimlerin, avukatların, savcıların, jüri kurumunun yer aldığı hukuk sistemlerinde jüri üyelerinin, yargılamayı takip eden insanların duygularını yönlendirmeyi amaçlayan bir yaklaşım, doğru bir örnek teşkil etmeyecektir. Pek çok yargılamada karşılaştığımız bu durum, karşımıza çıabilecek kimi duygulara karşı dikkatli olmamız gerektiğini ortaya koymaktadır ${ }^{60}$.

Michael L. Benson, "beyaz yaka suçluluğunu”' incelediği makalesinde, bir kişinin bir suçun faili olmakla suçlandığında bir "itibarsızlaştırma töreni" nin başladığını ifade eder ${ }^{61}$. İtibarsızlaştırma töreni, bir bireyin kamusal kimliğinin, toplum tarafından toplumsal ilişkiler bağlamında daha düşük kabul edilen bir şeye dönüştürüldügü süreçlerdir ${ }^{62}$. İște Benson'a göre, modern ceza yargılaması da tam olarak bir itibarsızlaştırma törenidir. Suçlunun ve suçun medyaya yansıması, suçlunun yalnızca kötülükler yapan bir "şey" olarak gösterilmesi ve okurlarda suçluya karşı öfke, nefret, iğrenme yaratılması itibarsızlaştırma sürecinin ilk adımıdır ${ }^{63}$. Benson, beyaz yakalı suçlularla yaptığ 1 mülakatlarda suçlulara göre suçlarının büyütüldüğünü, suçlunun kendisinin toplumun cezasına layık görülen bir nesneye dönüştürüldüğünü ortaya koyar. Bu mülakatlarda yer alan, zimmetine para geçirdiği gerekçesiyle yargılanan bir katılımcı, gazetelerde sürekli kendisinden bahsedildiğini, bu haberleri okuyan birisinin kendisini yaşamış en kötü suçlu olarak görebileceğini, geçmişinde yer alan iyi davranışlarına hiç yer verilmediğini belirtmiştir ${ }^{64}$. Katılımcıya uzun bir süre kendisini anlatma firsatı verilmemiş, kovuşturma ve yargılama süreci boyunca ritüel bir sessizliğe maruz bırakılmıştır, ardından eşit olmayan bir güç ilişkisinin varlığı hissettirilerek onun katılımın aranmadığı bir gerçeklik inşa edilmiştir ${ }^{65}$. Bu gerçeklikte o, başkalarının sempatisini hak etmeyecek kadar kötü bir kişidir, işlediği suçun cezasını hak etmiştir. Statüsünü ve itibarını kaybettiğini anlayan sanıkta utanç, öfke, aşağılanma ve düşmanlık duyguları kendilerini gösterir. Bu süreç neticesinde katılımcı, ailesinin kendisi hakkında olumsuz düşüncelere kapılacakları düşüncesinden kurtulamamış, yargılama boyunca artan bir öfkeye tutulmuş ve neticede suçunu reddetme noktasına gelmiştir. Çünkü süreç, karakterini tamamen tahrip etmiştir ${ }^{66}$.

Duyguların yargılamada kullanılmasına Samuel Pillsbury'nin kurguladığı örnek bir olayla devam edebiliriz. Pillsbury, jüri sisteminin olduğu bir hukuk düzeninde kü̧̈ük, kendi içine kapalı bir

\footnotetext{
${ }^{54}$ FLOWER, 2020, s.3.

${ }^{55}$ LITTLE, s.206. Yakın dönemde nörobilim alanındaki çalışmalar, rasyonellik ile duygusallığın ayrılamayacağını göstermiştir.

${ }^{56}$ Stina Bergman Blix ve Asa Wettergren, İsveç mahkemelerinde bu yönde bir araştırma yapmıştır. Bkz. BLIX, Stina Bergman/WETTERGREN, Asa, “A Sociological Perspective on Emotions in the Judiciary”: Emotion Review, 8(1), 2016, https://journals.sagepub.com/doi/pdf/10.1177/1754073915601226 (Erişim Tarihi: 23.10.2020)

${ }^{57}$ LITTLE, s.205.

${ }^{58}$ Pillsbury, s.673. Pillsbury, özellikle ceza davalarında duygusal tepkilerin doğal olduğunu belirtse de aynı duygusallığı hukuk davalarında görmemizi engelleyecek bir neden yoktur. Flower da duyguların tüm insan davranışlarının doğasında olduğunu ve mahkeme salonu da dahil olmak üzere tüm sosyal ilişkilerde gömülü halde olduğunu belirtir. FLOWER, 2020, s.4.

${ }^{59}$ LITTLE, s. 205

${ }^{60}$ Nitekim Lisa Flower da değerlendirme ve karar verme süreçlerinde duyguların destekleyici olmalarının önemine dikkat çekmiştir. Tarafsızlı̆̆ da duyguların yokluğu olarak değil, değerlendirmede nasıl ele alınmaları gerektiği açısından incelemiştir. FLOWER, "The (Un)emotional Law Student", s.296.

${ }^{61}$ BENSON, Michael L., "Emotions and Adjudication: Status Degradation Among White-Collar Criminals", Justice Quarterly, 7(3), 1990, p.517. https://www.researchgate.net/publication/248966576 (Erişim Tarihi: 23.10.2020)

${ }^{62}$ GARFINKEL, Harold, "Conditions of Succesful Degradation Ceremonies”, American Journal of Sociology, 61(5), 1950, p.420. https://www.jstor.org/stable/2773484 (Erişim Tarihi 23.10.2020)

${ }^{63}$ BENSON, s.519.

${ }^{64}$ BENSON, s.520.

${ }^{65}$ BENSON, s.524.

${ }^{66}$ BENSON, s.523.
} 
toplumda, topluma dışarıdan gelen bir yabancının toplumun sevilen üyelerinden biri olan kütüphaneci kadını kaçırdıktan sonra ona eziyet ettiğini, uzun işkence ve tecavüzlerden sonra onu öldürdügünü ve ölüm cezasıyla cezalandırılmak üzere jüri sisteminin bulunduğu mahkemenin önüne getirildiğini düşünmemizi ister ${ }^{67}$. Sanığın avukatı, müvekkilinin alkolik bir babayla büyüdüğünü, babasının onu istismar ettiğini kanıtlarıyla ortaya koymuş, savcılık makamıysa sanığın daha önce benzer şekilde işlenen iki suçla da bağlantısı olduğunu ileri sürmüştür. Hâkim, jüriden karar vermelerini istemiştir. Pillsbury'e göre aynı toplumun bir parçası olarak kendilerine saldırılmış gibi hisseden jüri üyeleri, toplumlarına dışarıdan gelerek saldıran bu yabancıya ölüm cezası verilmesine hükmedecektir. Pillsbury, bir kez de aynı suçun, toplumun bir üyesi tarafından işlendiğini düşünmemizi ister. Ona göre toplumdaki bireyler, elbette jüri üyeleri de sanığın geçmişini, kendisini istismar eden alkolik babasını biliyor olacaklardır. Sanığın çocukluğunu anımsamakta ve şu an "üzgün bir yüzle karşılarında oturan" sanığa karşı karmaşık duygular hissedeceklerdir. Böyle bir durumda, Pillsbury, jüri üyelerinin sanığı ölüm cezas1 yerine müebbet hapse mahkûm edeceklerini savunur ${ }^{68}$.

Görüldügü üzere bu örnekte duygular, sanığa verilecek cezanın belirlenmesinde etkili olmuştur. Duygular, yargılamada rol oynarken kolaylıkla kişiyi kontrol altına alarak onu yönlendirebilirler. Özellikle ceza yargılamasında suçluya yöneltilmek istenen öfke, suçlunun bir an önce bulunması isteğini körükleyerek yargılamanın detaylı bir şekilde yapılmasını engelleyebilir ${ }^{69}$. Jüri üyelerini etkileyen bu durum pekâlâ hâkimleri de etkileyebilir. Hâkim, duygularının karar vermesine izin vermemeli, karar vermeye yardımcı olması için duygularını, bu duygularının farkında olarak kullanmalıdır ${ }^{70}$. Peki bu nasıl gerçekleştirilebilir?

Yargılamada pek çok duygu, kendisine yer bulabilir. Nussbaum'un belirttiği gibi bütün toplumlar, duygularla doludur. Toplumun bir üyesi olan bireyler ve dolayısıyla hâkimler de elbette duygularla doludur. Laura Little da bu gerçekten yola çıkarak yargılamada empati, sempati, vefa, sadakat, minnettarlık, kıskançlık, iğrenme ve nefret gibi duyguların yerlerini tarafsızlık, bağımsızlık ve yeterlilik kavramları üzerinden tartışmıştır ${ }^{71}$. Özellikle vefa, sadakat, minnettarlık, kıskançlık, iğrenme ve nefret gibi duyguların hâkimin tarafsızlığına gölge düşürebileceğini ifade ederken, yalnızca hâkimlere değil yargılama sürecinin diğer aktörlerine de iş düştüğünü belirtmiştir ${ }^{72}$.

Daha önce iğrenmenin projektif bir yanının bulunduğunu ve çocukluğumuzdan başlayarak doğal iğrenmenin yanında toplumun iğrendiği şeylerden de iğrenmemiz gerektiğini öğrendiğimizi ifade etmiştik. Benzer bir durumu, diğer duygular için de söyleyebiliriz. Bilişsel faaliyetimizin ürünü olan duyguları, hangi durumlarda hissetmemiz gerektiğini çocukluğumuzdan itibaren öğrenmeye başlarız. Bu öğrenme bir noktadan sonra alışkanlığa dönüşür ve duyguların projektif olduğu gerç eğinin önüne geçer. Bu nedenle olaylar hakkında bir şeyler hissederken bu duygularımızın projektif olduğunu, kimilerinin (örneğin ceza yargılamasında öfke gibi) çok kuvvetli bir şekilde bizi etkileyebileceğini her zaman aklımızda tutmalıyız. Çünkü yargılamayı tehlikeye düşürebilecek duygular, bu duyguları hissedenlerin tanımadığı duygulardır: Bu duygulara kendini kandıran duygular diyebiliriz ${ }^{73}$. Sanığın ya da mağdurun ırkına, toplumsal konumuna, yaşayış tarzına duyulan öfkenin farkına varılmadan yargılamada, sanığın eylemlerine anlam yüklenebilir ya da mağdurun, yalnızca suçun işlendiği yerde bulunması dahi eleştirilebilir.

Önyarg1 ve farkına varılmayan duygular nedeniyle hâkimler kendilerini kandırarak yargılamanın taraflarına onların saygı duyulması gereken bireyler oldukları gerçeğinden ayrılarak davranabilirler. Özellikle tarafsızlık mitinin etkisiyle, tarafların gerçek durumlarını görmeyerek örneğin ceza yargılamasında sanığı "suçlu” olarak etiketler ve onu “öteki”" olarak tanımlayabilir. Bir suçun işlenmiş olmasının yarattığı öfkeye düşmemiş olduğu, tarafsızlığını koruduğu sanısıyla sanığın hikayesini anlatmasına dahi izin vermez. Böylece suçludan bir canavar yaratır ${ }^{74}$. Böyle bir hâkimin duygularını yargılamaya dahil etmediğini söyleyemeyiz.

Görüldüğü üzere duygular, yargılamada kullanmaktan kaçınamayacağımız, ancak kullanırken duygularımızın farkında olarak kullanmamız, onların karar vermesine ise izin vermememiz gereken

\footnotetext{
${ }^{67}$ PILLSBURY, s.664-665.

${ }^{68}$ PILLSBURY, s.665.

${ }^{69}$ PILLSBURY, s.693.

${ }^{70}$ PILLSBURY, s.704.

${ }^{71}$ LITTLE, s.205-218.

${ }^{72}$ LITTLE, s. 216.

${ }^{73}$ PILLSBURY, s.684. Nussbaum da her duygunun iyi bir rehber olmayacağını belirtir. İyi bir rehber olabilecek bir duygunun her şeyden önce neler olup bittiğiyle alakalı doğru bir bakış açısıyla değerlendirilmesi gerektiğini söyler. NUSSBAUM, 1995, s.74.

${ }^{74}$ PILLSBURY, s.692.
} 
araçlardır. Nussbaum da belirttiği üzere, duygular bize sorunları nasıl çözeceğini söylemezler; dikkatimizi, çözmemiz gereken sorunlar olduğuna çekerler. ${ }^{75}$ İşte hâkim, yargılamada duyguları alet çantasındaki bir aleti kullanan bir usta gibi kullanmalı, bir sorun olduğunu fark ederek duygularının etkisinde değil, duygularının yardımıyla karar vermelidir. Duygularını kullanırken öncelikle yargılamanın taraflarının duygu durumlarını tahayyül etmeli, onlara empati ve sempatiyle yaklaşarak önce onların duygu durumlarını anlamaya çalışmalıdır. Bazı düşünürler empati ve sempatinin yargılamada kullanılmalarının sorunlu olduğunu ileri sürerken diğer düşünürler, empati ve sempatinin hâkimin, kararından etkilenecek kişinin gerçek durumunu tasavvur etmesine olanak sağladıkları için bu kavramların yargılamada son derece önemli olduğunu savunurlar ${ }^{76}$.

\section{B. Yargllamada Sempati ve Empati}

\section{Sempati}

Sempati, diğer kişilerin duygularını anlamaya ve paylaşmaya ilişkin insan yeteneğidir. $\mathrm{Bu}$, kişinin diğer kişilerin etkisinde kalması değil; daha çok, diğerlerinin hissettiklerini ve kendi hissettiklerimizi anlamakla ilgilidir ${ }^{77}$. Nussbaum'un tahayyül etmekle ifade etmek istediği de kişilerden tam olarak bunu talep etmektedir. Bu tahayyül etme isteği, gerçekleştirilmesi o kadar da zor olan bir istek değildir. Nussbaum'a göre her insan, insan olmak ve insani değer bakımından eşit olduğu için insan nerede yaşarsa yaşasın ortak insani problemlerden söz edebiliriz ${ }^{78}$. Bu problemlerle şu an karşılaşmıyor olsak bile, gelecekte her zaman karşılaşma ihtimalimiz vardır. Bu yüzden, aklımızdan hiçbir zaman çıkarmamamız gereken şey, acı çeken insanların yaşadıkları acıların bir zaman bizim de başımıza gelebileceği düşüncesidir. Bu, sempati için kilit noktadır. Diğerinin bizim gibi insan olduğunu, başımıza gelen olayların, karşılaştığımız zorlukların onun da karşısına çıktığını, onun karşılaştığ zorlukların da bizim karşlaşabileceğimiz zorluklar olabileceği düşüncesi, sempati duygusunun ilk adımıdır. Diğerinin karşılaştığı engelleri görmek, bu engeller karşısında onun hissettiklerini anlamak, diğerinin insan dışı varlık olarak görülmesinin önüne geçmede çok önemlidir ${ }^{79}$.

Sempati, insanı diğer insanlarla bütünleştirir. Sempati, bu gizemli dünyada diğer insanın, kendi yolunu arayan bir gezgin olduğu kabulünden hareketle yolu onun için zorlaştırmak yerine kolaylaştırma tercihidir. ${ }^{80}$ Dünyayı onun gözünden görmektir. Sempatiyle tahayyül etme, bir insanın derisinin içine girip gezinmektir ${ }^{81}$. Radley'leri anlamaya çalışmaktır ${ }^{82}$, meseleye yalnızca korku, iğrenme, tiksinti gibi hoşnutsuz duygularla insanı görünmez kılarak yaklaşmak değildir. Bir başkasının ayakkabılarını giyip bir süre onlarla gezinmeyi tercih etmek, böylece tahayyül etme kabiliyetini geliştirerek hem diğer insanı hem de kendimizi görünür kılmak mümkündür.

\section{Empati}

Empati ise sempatiyle karıştırılmaya son derece müsait olsa da aslında, bu iki kavram arasında esaslı bir ayrım vardır. Heinz Kohut'a göre empatiyi iki farklı yol olarak görebiliriz: a) bir bilgi toplama etkinliği olarak empati ve b) insanlar arasındaki güçlü bir duygusal bağ olarak empati ${ }^{83}$. Nussbaum'a göre ise empati basitçe, diğerinin bakış açısını kullanarak diğerinin durumunu hayal etme yeteneğidir ${ }^{84}$. $\mathrm{Bu}$ açıklamasıyla Nussbaum'un, Kohut'un belirttiği iki farklı yoldan ikincisine yakın bir anlayış geliştirdiğini, ancak buna da bir itiraz getirdiğini söyleyebiliriz. Nussbaum empatinin sempati ve şefkatten (compassion) ayrılması gerektiğini, empatinin basitçe başka bir kişinin deneyiminin yaratıcı bir yeniden inşası olduğunu ifade eder. Burada empati kuran kişi, empati kurduğu kişinin deneyiminin iyi mi kötü mü, mutlu mu üzücü mü, acı verici mi yoksa mutluluk verici mi olduğunu düşünmez. Empati kurduğu kişinin durumunu iyi veya kötü olarak görmez, hatta kimi zaman örneğin sadist bir kişinin işkence ettiği kişiye empati kurarak onun kötü durumundan keyif alması gibi, empatiyi olumsuz

\footnotetext{
${ }^{75}$ NUSSBAUM, 1995, s.69.

${ }^{76}$ LITTLE, s. 209.

${ }^{77}$ UYGUR, s.160-161

${ }^{78}$ ERKIZAN, s. 133.

${ }^{79}$ NUSSBAUM, 2010, s.48.

${ }^{80}$ Nitekim teorisini oluştururken Aristoteles'in eudamonia kavramına yönelen Nussbaum'un Aristoteles'ten ayrlldı̆̆ önemli bir nokta budur. Nussbaum, insanların her birinin kendi farklı eudamonia'sını tasarlayıp gerçekleştirebileceği ön koşullara sahip olmasının yolunu açmaya odaklanmaktadır. ÇELİK, Elif: “İnsan Hakları Kavramını Nussbaum’un Yapabilirlikler Yaklaşımı İle Düşünmek", Arkhe-Logos Dergisi, (4), 2017, s.108.

${ }^{81}$ LEE, Harper, Bülbülü Öldürmek, çev. Özay Süsoy, Altın Kitaplar Yayınevi, İstanbul 2013, s.41.

${ }^{82}$ LEE, s.318. Radley ailesi hakkında kitap boyunca çeşitli dedikodulardan bahsedilir. Scout ve Jem, Boo Radley ile tanışana kadar bu dedikodularla Radley’lerden korkarlar. Kitabın sonunda fikirlerini değiştirecek bir deneyim yaşarlar.

${ }^{83}$ KOHUT, Heinz, "Introspection, Empathy and Mental Health", The International Journal of Psycho-Analysis, (63), 1982, p.3 https://manhattanpsychoanalysis.com/wp-content/uploads/Kohut-Introspection-Empathy-and-the-Semi-Circle-of-MentalHealth.pdf, s.3. (Erişim Tarihi: 23.10.2020)

${ }^{84}$ NUSSBAUM, 2013, s.145.
} 
bir şekilde kullanabilir. Halbuki sempati ve şefkat, karşıdaki kişinin durumunun kötü olduğuna ilişkin değerlendirmemizi içerir ${ }^{85}$.

Nussbaum'a göre empati, yetenekli bir aktörün rolüne zihinsel olarak hazırlanması gibidir. Acı çeken kişinin durumunun kabulünü içerir, ancak her zaman kişinin kendisinin acı çekmeyeceği bilinciyle birleştirilir. Empati için kişi, acı çekenle aralarında nitelik farkının olduğunun ayırdında olmalıdır. Bu esasında kişiyle diğeri arasındaki yaratıcı bir yer değiştirmedir. Örneğin dudakları yaralanan bir fagot sanatçısının durumuyla empati kurabilmek için onun bizden nitelik olarak farklı olduğunun bilincine sahip olmamız gerekir ${ }^{86}$. Bu farkındalık çok önemlidir. Nussbaum için önemli olan diğer kişinin hayatında neler olduğunu gerçekten anlama ve endişeleri, üzüntüleriyle bağlantı kurabilmedir.

Nussbaum'un empatiye yönelik endişelerini Elena Pulcini de paylaşmaktadır. Empatiyi “ötekini keşfetme" olarak tanımlayan Pulcini, ötekinin varlığını kabul ederek ötekinin de içinde yaşadığımız dünyanın parçası olduğunu, ötekini kendimizden farklı olarak tanımayı ama onun da bizim gibi duygulara, düşüncelere, arzulara sahip olduğunu kabul etmek anlamına geldiğini ifade etmiştir ${ }^{87}$. Bununla birlikte Pulcini'ye göre empati, başkalarının duygu ve deneyimlerinin değerine dair bir yargıya işaret etmediğinden otomatik olarak etik problemlere uygulanabilir bir cevap üretmez. Temelde sosyal bir kapasite olduğu için ötekinin duygusal durumunda yer almamıza ve ötekinin bakış açısını benimsememize izin veren empatidir. Yani empati, ötekinin deneyimini anlamamıza ve ona katılmamıza izin verir. Ancak bu katılım, ahlaki duyarlılık içermek zorunda olmadığından tek başına yeterli değildir ${ }^{88}$.

Nussbaum ve Pulcini'nin empati hakkındaki çekincelerini Thomas Morawetz paylaşmaz. Ona göre oyunbaz bir hayal gücü ve mantığın rehberliğindeki empati her zaman iyi bir şeydir. Özellikle hâkimler söz konusu olduğunda, empatik bir karar mutlaka empatik olmayan karardan daha iyidir ${ }^{89}$. Morawetz'e göre empatinin taşıdığı iddia edilen sorunlar nedeniyle empatiyi ve duygularımızı göz ardı etmek, iyi bir sonuç vermeyecektir. Çünkü hayal gücünü, ötekinin yaşantısına girmek ve hem onunla benzerliklerini hem de farklılıklarını kavramak için kullanmayan birey, kendisini duygusuzluğa ve ahlaki yetersizliğe mahkûm etmiş olur. Empati, özellikle hâkime hem ötekine yakınlığı hem de adalet için gereken mesafeyi verdiğinden onun bir çırpıda reddedilmesi doğru değildir ${ }^{90}$.

Şüphesiz empati ve sempati kavramları, yargılamada kullanılacak araçlar arasında akla ilk gelenlerden değildir. Hatta bir adım daha ileri giderek, bu kavramların yargılamada kullanılmasının olumsuz karşılandığını dahi söyleyebiliriz. Örneğin sempatinin sempati duyan hâkim ve sempati duyulan kişi arasında ilişki kurulmasını gerektirdiği için hâkimi, tarafların bakış açılarına gereğinden fazla bağımlı kılabileceği, bu nedenle de onu körleştirebileceği ifade edilmiştir ${ }^{91}$.

Hâkimin işi bir etik ilişkidir. Etik ilişki, belirli bir kişinin belirli bir kişi ile ya da bir insan durumu ile ilişkisi olup bu kişiler gerçek kişiler, insan durumu ise belirli, bir defalık bir durumdur ${ }^{92}$. Bir etik ilişkide olan hâkimin de değerlendirdiği, bir olay ve bunun aracılığıyla o olayı oluşturan kişilerin eylemleridir ${ }^{93}$. Bu noktada doğru değerlendirme de değerlendirilen eylem ya da tutum bakımından koşulları o eylemin içinde yapıldığı gerçeklik koşullarını yeterince bilmek ve eylemi yapan kişiyi yeterince tanımayı gerektirir. Eylemin içinde yapıldığı gerçeklik koşulları ile eylemi yapan kişiye dair bilgiler, değerlendirene (hâkime) davranıştan arka planına, o belirli eylemin oluşturucularına ulaşmasında yardımcı olur ${ }^{94}$. Bir kişinin bir eyleminin, bir kararının veya bir tutumunun doğru değerlendirilebilmesi, bunu değerlendirenin, o kişinin yapı bütünlüğünü tanımasını, onun nasıl bir insan olduğunu, bu eylemi yapanın kim olduğunu bilmesini; ayrıca da bunu ne gibi koşullarda, nasıl bir durumda yaptığını bilmesini şart koşar ${ }^{95}$. Doğru değerlendirme için hikâyenin mümkün olan bütün açıklığıyla bilinmesi gerekir. Bunu sağlamanın araçlarının başında da empati ve sempati gelir.

\footnotetext{
${ }^{85}$ NUSSBAUM, 2001, s.302.

${ }^{86}$ NUSSBAUM, 2001, s.328.

${ }^{87}$ PULCINI, Elena, “'What Emotions Motivate Care?’, Emotion Review, 9(1), 2017,

https://journals.sagepub.com/doi/pdf/10.1177/1754073915615429, s.66. (Erişim Tarihi: 23.10.2020)

${ }^{88}$ PULCINI, s.66.

${ }^{89}$ MORAWETZ, Thomas, "Empathy and Judgment", Yale Journal of Law \& the Humanities, 8(2), Art. 8, 1996, s.518.

http://digitalcommons.law.yale.edu/yjlh/vol8/iss2/8, (Erişim Tarihi: 24.10.2020)

${ }^{90}$ MORAWETZ, s.523.

${ }^{91}$ LITTLE, s.209-210.

${ }^{92}$ KUÇURADİ, İoanna: Etik, Türkiye Felsefe Kurumu, Ankara 2018, s.7.

${ }^{93}$ KUÇURADİ, s.14.

${ }^{94}$ KUÇURADİ, s.22.

${ }^{95}$ KUÇURADİ, İoanna, İnsan ve Değerleri, Türkiye Felsefe Kurumu, Ankara 2013, s.62.
} 
Hâkim, önüne gelen her davada, kendisini taraflara karşı sorumlu hissettiği için her davaya kendi biricikliği, tekliği çerçevesinde bakmalıdır. Her davanın biricikliğinin, tekliğinin anlaşılması devamında her davada yeni, kendine has bir yargılama yapılmasını gerektirir. İşte bu yargılamanın gerçekleşebilmesi için hâkimin bağlama göre hareket etmesi şarttır ${ }^{96}$. Empati ve sempati, hâkime bağlama göre hareket etme imkânı tanır. Ancak bu şekilde davranarak hâkim, kendisinden tam olarak ne talep edildiğini, tarafların ne istediğini görebilir ve bu görme neticesinde adil kararın olanaklılığ üzerine düşünebilir. Elbette ilk adım dinlemedir. Uygur'a göre hâkim, tek olan olayı anlayabilmek için tarafların konuşmasına izin vermeli, onları açık yüreklilikle dinlemelidir. Hâkim, özellikle bir taraf durumu açıklıkla ortaya koyamamışsa, onun konuşmasına müsaade etmeli, her iki tarafa eşit sempatiyle yaklaşarak olayı kavramaya çalışmalıdır ${ }^{97}$. İşte yargılamada, sempatinin ortaya çıktığ nokta burasıdır. Sempati ve hatta empati, hâkimin kendi yaşamının dışında da bir dünya olduğunu, bu dünyadaki karmaşık problemlerde problemlere dahil olan herkesin hayatını etkileyecek kararları vermesine yardımcı olacaktır ${ }^{98}$. Empati ve sempatinin, yargılamada karşı karşıya gelen iki zıt düşünceyi kavramada hâkime yardımcı olacak en önemli araçlar olduğu söylenebilirr"

Empati ve sempati kavramlarıyla ilgili olarak dikkat çekilmesi gereken ilk nokta, iki kavramın da hâkimi, davanın taraflarına karşı konumlandırdığıdır. Hâkim, kendi konumunun bilincinde olduğu sürece, bu konumlandırmayı yargılama sırasında kullanarak adil kararı vermede önemli bir adım atar. Çünkü empati ve sempati kavramlarına başvururken hâkim, yalnızca bir tarafın etkisinde kalmadığı gibi sadece kendi iç dünyasına da bakmamakta, adil bir karar vermek için kendisine dişarıdan bakmaktadır ${ }^{100}$. Böylelikle tarafların birinin yanında yer almadığı gibi, tarafları dışlayan ve onları bir nesne haline getiren yargılama türünden de uzak durmaktadır. Her iki tarafı da dinleyerek onlara empati ve sempatiyle yaklaşan hâkim, tarafların önüne gelen uyuşmazlıktaki konumlarını belirleyecek, davranışlarının altında yatan nedenleri bulacak ve kendisinden talep edileni daha iyi kavrayacaktır. Bunların yanı sıra, taraflar karşısında kendi konumunu fark edecektir. Nussbaum'un empatiyi, kişiyle diğeri arasındaki yaratıcı bir yer değiştirme olarak gördüğünü ifade etmiştik. Bu yer değiştirmeyle hâkim, taraflar karşısında kendi konumunu daha iyi belirleyebilir ve gerek tarafların birbirlerinden gerek de yargılama sırasında hâkimin kendisinden ne talep ettiklerini daha kolay belirleyebilir. $\mathrm{Bu}$ belirleme, hâkimin yargılamadaki otoritesini artıracak bir gelişmedir ${ }^{101}$. Hâkimin kendilerini dinlediğini, talep ettiklerini anladığını hisseden taraflar, hâkime saygı duyarak onun yargılamadaki otoritesini kabul edecek, böylelikle haklarında verilen kararın yetkin bir hâkimin gerçekleştirdiği yetkin bir yargılamanın ardından verildiğine daha kolay ikna olabileceklerdir.

Sempatinin yanında yer alan empati, çoğunlukla "tuhaf", "mistik" ya da "sezgisel" bir fenomen olarak görülse de aslında hukuki sorunlara zengin bir yaklaşım kaynağıdır. Empati hâkime, önüne gelen hukuki problemin taraflarca nasıl anlaşıldığını görmesinde ve yeni bir bakış açısı edinmesinde yardımcı olur. Yaratıcı bir deneyim olarak empati, yargılamanın taraflarının perspektifinden olaya yaklaşmayı sağlayarak hâkimin "anlayış evrenini" genişletecektir ${ }^{102}$. Genişleyen anlayış evreniyle hâkim, yargılama sırasında alternatif bir bakış açısı kazanacaktır. Duyguların etkisiyle olumsuz ilerleyebilecek bir yargılamanın, örneğin bir ceza yargılamasında öfkeyle sanığa yönelmenin tehlikelerini ancak alternatif bakış açılarıyla aşabiliriz. Sanığın eylemi, eylemin gerçekleştiği koşullar üzerinde düşünerek, mağdur ve sanıkla empati ve sempati kurarak onların durumunu tahayyül ederek alternatif bakış açıları kazanabilir, tek tip, özellikle yargılamanın hızlıca bitirilmesini talep eden bir sistemde bunu sağlamaya yönelik bir bakış açısına alternatif yaklaşımlar getirebiliriz. Böylece empatinin, ceza yargılaması örneğinde, mantıksız sebeplerle sanığa yöneltilen öfkenin önüne geçmesini ${ }^{103}$, duygulara kapılarak eksik bir araştırma yapılmasını ve kanaatlerle karar verilmesini önleyeceğini söyleyebiliriz. Bir hâkim kararına, suçlunun duyguları ve suça maruz kalanın çektiği acıyı anlayarak ulaşır'104.

\section{Hâkimin Tarafsızlığı Karşısında Empati ve Sempati}

Sempati kavramından daha tartışmalı olan empati kavramı, özellikle hâkimin tarafsızlığına aykırı bulunduğu için pek çok düşünür tarafından reddedilmiştir. Bu düşünürler empati ve sempatiye

\footnotetext{
${ }^{96}$ UYGUR, s.156.

${ }^{97}$ UYGUR, s.157.

${ }^{98}$ LITTLE, s. 210 .

${ }^{99}$ LITTLE, s.210.

${ }^{100}$ UYGUR, s. 161

${ }^{101}$ LITTLE, s.210.

${ }^{102}$ HENDERSON, s.1576-1581.

${ }^{103}$ PILLSBURY, s.694.

${ }^{104}$ UYGUR, s.161.
} 
şüpheyle yaklaşırken, aslında bir noktayı gözden kaçırmaktadırlar. Hukuk, günlük hayatı konu alır ve ondan beslenir. Daha önceki başlıklarda belirtildiği üzere empati, başkasının yerine kendini koymakla, başkasının hissettiğini paylaşmak ve anlamakla ilgilidir. Empati, insanların motivasyonlarını, niyetlerini ve algılarını anlamaya hizmet eder ${ }^{105}$. Bu açıdan sempatiyle benzer olduğu görülmektedir. Ancak empati başkasının duygularını hissetmek iken sempati, başkasının duygularını anlamaktır ${ }^{106}$. İki kavram arasındaki farklılığa baktığımızda empatinin başkalarının ne hissettikleri hakkında, sempatinin ise başkalarının acılarına ilişkin ilgimizi ortaya koyan ahlaki duygu olduğunu görürüz ${ }^{107}$. Empati, başkalarının perspektifine ilişkin bilgiye ulaşmayı sağlarken davranışa ilişkin motivasyon sağlamaz. Sempati ise sağlar. Aslında bu farklılık nedeniyle bu iki kavramın yargılamada birlikte kullanılması önemlidir. Çünkü baktığımızda, iki kavramın birbirini tamamladığı görülecektir ${ }^{108}$.

Empati ve sempatiyi doğal olarak öncelikle bizim gibi olan, bize benzeyen bireylerle kurarı. Ötekiyle empati ve sempati duymak daha zordur ${ }^{109}$. Bir ceza yargılamasında yukarıda ifade ettiğimiz itibarsızlaştırma sürecinin ardından sanık, ötekileştirilir ve onunla empati ve sempati yapılması daha zor hale gelir. Benzer şekilde, özel hukuk yargılamasında taraflardan birinin hâkimle olan benzerliği, empati ve sempatinin kendisine yöneltilmesini kolaylaştırırken karşı taraf için aynı durum söz konusu olmayacaktır. Çünkü taraflardan biri, öteki ya da nesne konumuna düşürülerek empati ve sempati yapılacak birey olmaktan çıkarılır. Hâkim tarafından kimi zaman farkında olmadan gerçekleştirilen bu durum, onun tarafsızlığını etkileyebilir. Bu nedenle hâkimin tarafsızlığını sağlayabilmesi için zor olanın peşinde koşması, yani ötekiyle de empati ve sempati kurmak için çaba göstermesi gereklidir.

Hâkim, yargılamanın taraflarıyla empati kurarak kendini onların yerine koyacak, onların hissettiklerini hissetmeye çalışacaktır. Sempatiyle de onların duygularını anlamak için çabalayacak, ancak sadece bununla kalmayarak onları motive eden nedenleri de anlamaya uğraşacaktır ${ }^{110}$. Yargılamada empatiye karşı çıkanlar ise empatinin olumsuzluklarından bahsederek empati duymanın anlamının, tamamıyla başkasının perspektifini almak olduğundan bahisle başkasının perspektifini tamamıyla almanın hukuki süreçte mümkün olmadığını, bunun hâkimin tarafsızlığına zarar vereceğini savunmaktadır ${ }^{111}$. Burada, yargılama faaliyetinin düşünümselliğini göz ardı etmemek gerekir. Eleştiriler ışığında, tek başına empati kavramının yargılamanın tarafsızlık görünümüne zarar vereceği kabul edilebilirse de sempatiyle birlikte kullanıldığında empatinin, hâkimin elinde önemli bir araç olacağı ortadadır. Her şeyden önce, hâkimin elinin altındaki araçlardan sadece biri olması, hâkimin yargılamayı yapmada başka araçlarının da bulunması başlı başına empatiye dayalı bir yargılamanın yapılmasını ihtimalini azaltmaktadır. Buna ek olarak sempati yargılamasıyla kendisinin ve yargılamanın taraflarının konumlarını belirleyen hâkimin bu konumlar çerçevesinde empati yargısını gerçekleştirmesinin önünde bir engel görünmemektedir.

Hâkimin, bir başkasının perspektifini tamamen almasının, onun tarafsızlığına gölge düşürebileceği yönündeki itiraz açısından belirtilmesi gereken hâkimin henüz karar verme aşamasına geçmeden, önüne gelen uyuşmazlığın biricikliğini, tekliğini anlama noktasında her iki tarafın da perspektifini görmesinin adil bir karar için gerekli olduğudur. Taraflardan yalnızca birini dinleyen; diğer tarafi, sırfo tarafa karşı tiksinme/iğrenme beslediği için dinlemeyen, onu sessizliğe mahkûm eden hâkim, yalnızca bir tarafın perspektifini almış olacaktır. Yargılamada tehlikeli olan da budur. Yalnızca bir tarafın perspektifinin tamamıyla alınması ya da tarafların özne olarak dikkate alınmaması, esasında tarafsızlığa aykırı olan da budur. Çünkü tarafsız hâkim idealinde, çıkarlara dayanmayan, nötr, her iki tarafın ileri sürdüklerini eşit olarak değerlendiren ve objektif ilkelere dayalı olarak hareket eden

\footnotetext{
${ }^{105}$ BLIX/WETTERGREN, s.33.

${ }^{106}$ UYGUR, s.163.

${ }^{107}$ UYGUR, s.164.

${ }^{108}$ Fransızca "sympathie" kelimesinden dilimize geçen sempati, duygusal yakınlık, duygudaşlık anlamına gelirken Eski Yunanca aynı anlama gelen sympathía veya sympátheia $\sigma 0 \mu \pi \alpha \dot{\theta} \theta \varepsilon ı \alpha$ sözcüğünden alıntıdır. Bu sözcük Eski Yunanca pás $\chi \overline{0}$, path- $\pi \dot{\alpha} \sigma \chi \omega, \pi \alpha \theta-$ "hissetme, acı duyma" fiilinden türetilmiştir. Empati ise İngilizce "empathy, "içinde duyma" anlamına gelmektedir. İngilizce sözcük, Eski Yunanca patheía $\pi \alpha \theta \varepsilon i ́ \alpha$ "hissetme, duyma" sözcügünden türetilmiştir. Bu sözcüğün kökü de Eski Yunanca pás $\chi \overline{0}$, path- $\pi \alpha ́ \sigma \chi \omega$, $\pi \alpha \theta$ - "hissetmek, acı duymak" fiilidir. Bakıldığında sempati ve empati kelimelerinin aynı kökten gelmeleri de aralarındaki bağlantıyı ortaya koymaktadır. Detaylı inceleme için bkz. https://www.nisanyansozluk.com/?k=sempati\&view=annotated ve https://www.nisanyansozluk.com/?k=empati\&view=annotated (Erişim Tarihi: 30.12 .2020 )

${ }^{109}$ HENDERSON, s. 1584 .

${ }^{110}$ UYGUR, s.161, 164.

${ }^{111}$ UYGUR, s.165.
} 
hâkimin yer aldığı düşünüldüğünde ${ }^{112}$, empati ve sempati kavramlarının hâkime, yargılamanın taraflarının ileri sürdüklerini eşit olarak değerlendirmede yardımcı olduğu görülecektir. ${ }^{113}$

$\mathrm{Bu}$ açıdan bakıldığında, birlikte kullanıldıkları takdirde empati ve sempatinin, Nussbaum'un yaklaşımına aykırı olmadığı, tam aksine onun " anlam arayışııda insanlara saygı duyulması gerekir" şeklinde özetlenebilecek düşüncesiyle örtüştüğü rahatlıkla söylenebilir. Nussbaum'un karşı çıktığ "iğrenmenin politikası" düşüncelerine sahip ve tiksinme/iğrenme duygularıyla yargılama yapan hâkimler yargılamanın taraflarına önyargıyla yaklaşmış, onların taleplerine kulaklarını tıkamış, davranışlarının altındaki motivasyonu aramak yerine projektif iğrenmeden hareket ederek kendilerini yargılamanın taraflarının yerine koyma, onları anlamayı baştan reddetmişlerdir. Buradaki sıkıntı, objektif ilkelere dayanılmadan tarafların ileri sürdüklerinin reddedilmesidir. Hâkim, projektif iğrenmenin etkisi altında, yalnızca kendi iç dünyasına bakarak tarafsızlığını koruduğunu düşünüyor olabilir. Ancak hiçbir objektif ilkeye dayanmaması ve yargılamanın taraflarını taraf olarak dikkate almaması, tarafsızlık mefhumunun anlaşılması açısından sıkıntı olduğunu ortaya koymaktadır.

Peki hâkim tarafsızlığını ihlal etmeden, empati ve sempatiyi nasıl kullanabilir? Kabul etmek gerekir ki "hâkimin kendi deneyimleri" ifadesi, zihinlerde çoğu zaman olumsuz fikirler oluşturur. Halbuki burada, hâkimlerin kendi deneyimlerinden hareket etmelerinin anlamı, bencilce istekleri ve önyargıları içeren ve değer sorunları üzerine hesaplaşmaya girmemiş bir deneyimden hareket etmek demek değildir, öncelikle kendi deneyimlerinden hareket edecek hâkimin, açık fikirli olması gerekir ${ }^{114}$. Hâkim, yargılamanın taraflarına karşı olduğu kadar, hatta belki de daha fazla kendi deneyimlerine açık fikirlilikle yaklaşmalı, deneyimlerinden hareket ederek vereceği kararın adaletsizliğe yol açabileceği ihtimalini değerlendirmelidir. Sempatiden, empatiden yoksun, etik kaygıları taşımadan sadece kendi deneyimlerinden hareket eden hâkimin adil bir karar vermesi çok güçtür.

Uygur'a göre açık fikirli olmanın bir gereğini, ön yargılı olmamak veya belirli bir grubun yanında olmamak oluşturmaktadır ${ }^{115}$. Açık fikirli hâkim, belirli gruplara ilişkin özel ilgi göstermeyen veya onlara düşmanca davranmayan ve davanın tarafları karşısında kendi kişisel çıkarlarını düşünmeyen hâkimdir ${ }^{116}$. Açık fikirli hâkim, önündeki davaya belirli inançlarla gelmez, kendisine haklı nedenler sunulunca bu inançlarını değiştirmeye açıktır ${ }^{117}$. Değiştirdiğ fikirlerini yeniden oluşturmasında hâkimin elindeki en önemli araçlar da empati ve sempatidir. Empati ve sempatiyle hâkim, fikirlerini yeniden oluşturacağı konu hakkında bilgi sahibi olur, çünkü fikirlerin yeniden oluşturulmasında, o konuda belirli bilgiye sahip olunması gerekir ${ }^{118}$. Açık fikirlilik sayesinde hâkim, tarafsızlık açısından sorun yaşamadan tarafları dinleyebilir. Ön yargılarının, yanılabilirliğinin farkında olan ve bu farkındalıkla hareket eden hâkim, empati ve sempatiyle hareket ederek tarafların itirazlarını gerçekten duyabilir; daha da önemlisi tek durumun özelliklerini daha da kolay bir şekilde keşfedebilir. Çünkü tek olan kaçınılmazdır ${ }^{119}$ ve tek olan karşısında hâkimin ayakta durabilmesinde empati ve sempati, onun en önemli yardımcılarındandır. Tek olanın karşısına, onu gerçekten anlamak için çıkan hâkim, açık fikirli olduğu ölçüde kendi çıkarlarının peşinde koşmamış ve tarafları görünür kılarak tarafsızlığını korumuş olacaktır. Kuçuradi'nin ayrımındaki üçüncü tip hâkim de bu amaçla yola çıktığından tarafsızlığından şüpheye düşmeden empati ve sempatiyi kullanacak, adil karara bir adım daha yaklaşacaktır ${ }^{120}$.

\footnotetext{
${ }^{112}$ UYGUR, s.183.

${ }^{113}$ Nussbaum, yargıçların şairler gibi olmalarını ister. Nussbaum'a göre şairler sadece soyut düşünceler sunan kişiler değil, ele aldıkları vakaların tarihsel ve insani karmaşıklıklarına uygun adil yargılar sunarlar. Hatta Nussbaum bir adım daha ileri gidip -biraz da şairleşerek- hakimlerin güneş gibi olmalarını ister. Nasıl ki güneş bir şeyi aydınlattığında her köşeyi aydınlatır, hiçbir şey karanlıkta kalmaz, işte Nussbaum'a göre hakimler de önlerine gelen olaylara bu şekilde yaklaşmalıdır. Nussbaum'un şair-yargıç düşüncesi hakkında daha detaylı bilgi için bkz. NUSSBAUM, 1995, s.81-91.

${ }^{114}$ UYGUR, s.168.

${ }^{115}$ UYGUR, s.168.

${ }^{116}$ UYGUR, s.168-169.

117 UYGUR, s.71.

118 UYGUR, s.71.

119 UYGUR, s.154.

120 İoanna Kuçuradi'ye göre üç farklı hâkimlik anlayışı vardır. Üç hâkimlik anlayışından birincisinde hâkim, temsil ettiği "grup" adına, yani o grubun koyduğu normlar, yasalar, kurallar adına yargılar. Bu tarz bir yargılamayı yapan hâkim, kendisini grubuna karş1 bu yasalardan sorumlu duyan hâkimdir. Esasında burada hâkim, yargılamayı yaparken kişileri değil, toplumsal düzeni korumayı amaçlar. Bu nedenle bir kişinin bir eyleminin yapılmaması gereken bir eylem olup olmadığına da eylemi yapan kişi ya da eylemin yapıldığı durum aracılığıyla değil, o eyleme grubunun normlarının taktığı ada göre karar verir. İkinci tür hâkimlik anlayışında hâkim, insan olma adına, değer korumaya yönelik genel ilkeler adına kişi eylemlerini yargılar. Bu tarz bir yargılamayı yapan hâkim, kendisini insana karşı bu taleplerden sorumlu duyan hâkimdir. Böyle bir hâkim, kişileri yargılarken esas olarak, yine kişileri değil; bu genel ilkeleri korumayı amaçlar. Sonuncu hâkimlik anlayışında ise hâkim, kendisini yargıladığı insanlara karşı sorumlu duyar. O kendisini, belirli ilişkilerinde tarafların her birinin hakkını belirlemekten sorumlu görür. Böyle bir hâkim, yargılamayı
} 


\section{SONUÇ}

Duygular, yasa yapım sürecinin başlangıcından hâkim tarafından verilen hükme kadar geçen bütün süreçte, sürecin aktörlerini etkiler. Bu sürecin "yargılama" ayağında duyguların kullanılmasının kabul edilmemesi, artık geride kalmış bir anlayıştır. Modern hukuk sistemlerinin yapması gereken, duygu teorilerine gereken önemi vererek yargılamada duyguların nasıl ve ne ölçüde kullanılması üzerine düşünmektir. Bu çalışmada, Martha C. Nussbaum'un duygu teorisinden hareket edilerek yargılamada duyguların önemi üzerinde durulmuş, empati ve sempati kavramlarının hâkimlerin elinde önemli araçlar olabileceği sorusunun peşinden gidilmiştir. Kanaatimizce hâkim, yargılama sürecinde empati ve sempati kavramlarını etkili bir şekilde kullanarak hukuki uyuşmazlığın özüne ulaşmada ilk adımı atacak, bu doğru ilk adımı takip eden doğru değerlendirme faaliyetiyle somut olanın bilgisine ulaşarak adaleti gerçekleştirecek kararı verecektir. Tarafsızlık efsanesi sisinin arkasına sığınmadan, tarafları görecek ve gerçekten neler talep ettiklerini anlayacak bir yargılamanın ilk adımı, hâkimin duygularının farkında olmasıdır. Sosyal temelli birtakım olumsuz duygularının etkisinde olduğunu fark etmeyen hâkim, belki tarafsızlığını koruduğunu düşünebilir; ama esasında taraflar arasında bir ayrım yaparak yargılamanın henüz başında tarafsızlığını kaybetmiş olacaktır. Bir insan faaliyeti olan hukuk, insanın parçası olan duygulardan doğru bir şekilde yararlanmayı öğrendiği takdirde, adaleti gerçekleştirme amacına bir adım daha yaklaşacaktır.

\section{KAYNAKÇA}

BENSON, Michael L.: "Emotions and Adjudication: Status Degradation Among White-Collar Criminals", Justice Quarterly, 7(3), 1990, https://www.researchgate.net/publication/248966576_Emotions_and_Adjudication_Statu s_Degradation_Among_White-Collar_Criminals (Erişim Tarihi: 23.10.2020).

BLIX, Stina Bergman/WETTERGREN, Asa: "A Sociological Perspective on Emotions in the Judiciary"; Emotion $\quad$ Review, 8(1), 2016, https://journals.sagepub.com/doi/pdf/10.1177/1754073915601226 (Erişim Tarihi: 23.10.2020).

ÇELIK, Elif: “İnsan Hakları Kavramını Nussbaum'un Yapabilirlikler Yaklaşımı İle Düşünmek”, Arkhe-Logos Dergisi, (4), 2017.

ERKIZAN, H. Nur Beyaz: "Küresel Politik Liberalizmde (Global Political Liberalism) İnsan ve Eğitim”, Aristoteles’ten Nussbaum'a İnsan içinde, Sentez Yayıncılık, İstanbul 2012.

FLOWER, Lisa: “Doing Loyalty: Defense Lawyers' Subtle Dramas in Courtroom”, Journal of Contemporary Ethnography,

https://lup.lub.lu.se/search/ws/files/13744216/Doing_loyalty_final_draft.pdf (Erişim Tarihi: 22.10.2020).

FLOWER, Lisa: "The (Un)emotional Law Student", Int. J. Work Organisation and Emotion, 6(3), https://www.soclaw.lu.se/sites/soclaw.lu.se/files/the-unemotional-law-student_0.pdf (Erişim Tarihi: 22.10.2020).

GARFINKEL, Harold: “Conditions of Succesful Degradation Ceremonies”, American Journal of Sociology, $61(5)$,

1950 https://www.jstor.org/stable/pdf/2773484.pdf?refreqid=excelsior\%3Ac88eb6df127cee59 8355488bd40b824a (Erişim Tarihi 23.10.2020).

GÜVEN, Ebru: “'Martha C. Nussbaum’un İnsani Gelişme Olanaklar Yaklaşımı'”, Arkhe-Logos Felsefe Dergisi, (4), 2017.

HART, H. L. A.: $\quad$ Hukuk, Özgürlük ve Ahlak, Dost Kitabevi Yayınları, Ankara 2014.

HENDERSON, Lynne H.: "Legality and Empathy"; Scholarly Works, Paper 870. http://scholars.law.unlv.edu/cgi/viewcontent.cgi?article=1893\&context=facpub (Erişim Tarihi: 24.10.2020).

JOHNSON, Gregory: Theories of Emotion, https://www.iep.utm.edu/emotion/ (Erişim Tarihi: 20.10.2020).

KOHUT, Heinz: "Introspection, Empathy and Mental Health', The International Journal of Psycho-Analysis içinde, https://manhattanpsychoanalysis.com/wp-content/uploads/Kohut-IntrospectionEmpathy-and-the-Semi-Circle-of-Mental-Health.pdf (Erişim Tarihi: 23.10.2020).

KUÇURADİ, İoanna: Ahlâk, Etik ve Etikler, Türkiye Felsefe Kurumu, Ankara 2019.

KUÇURADİ, İoanna: Etik, Türkiye Felsefe Kurumu, Ankara 2018.

gerçekleştirirken önüne gelen ilişkilerinde karşı karşıya gelmiş iki tarafın hakkını aynı anda korumaya çalışan hâkimdir. Böyle bir hâkimlik anlayışında yargılama eylemi, bakılan eylemi yapmama olanağının olup olmadığına bakma; "yapılmaması gerekeni", davalının yaptığı ileri sürülen eylemi o koşullarda yapılabilir olanlara göre değerlendirmedir. Bu yargılamada hâkimlik, belirli bir eylem için “"kriter”' belirleme olur. Bu kriter ise, “o koşullarda yapılabilir olandır." KUÇURADİ, İoanna: Ahlâk, Etik ve Etikler, Türkiye Felsefe Kurumu, Ankara 2019, s.106-108. 
KUÇURADİ, İoanna: İnsan ve Değerleri, Türkiye Felsefe Kurumu, Ankara 2013.

LEE, Harper: Bülbülü Öldürmek, çev. Özay Süsoy, Altın Kitaplar Yayınevi, İstanbul 2013.

LITTLE, Laura: "Adjudication and Emotion", Florida Coustal Law Journal, 3, https://heinonline.org/HOL/Page?handle=hein.journals/fclj3\&id=211\&collection=journal s\&index $=($ Erişim Tarihi: 22.10.2020).

MILL, John Stuart: Özgürlük Üstüne ve Seçme Yazılar, Belge Yayınları, İstanbul 2016.

MORAWETZ, Thomas: “Empathy and Judgment”, Yale Journal of Law \& the Humanities, 8(2), Art.8 içinde, http://digitalcommons.law.yale.edu/yjlh/vol8/iss2/8 (Erişim Tarihi: 24.10.2020).

MUTLU, Barış: Martha Nussbaum'da İyi Yaşam ve Duyguların Yeri, Current Debates in Philosophy \& Psychology, V.11, Editör: Bora Erdağı, https://books.google.com.tr/books?id=vNJFDwAAQBAJ\&printsec=frontcover\&hl=tr\#v $=$ onepage $\& q \& \mathrm{f}=$ false $($ Erişim Tarihi: 21.10 .2020$)$

NUSSBAUM, Martha C.: From Disgust To Humanity, Oxford University Press, 2010.

NUSSBAUM, Martha C.: "İnsanlığın Hukuk Eğitiminde Geliştirilmesi'”, (Çev. Aysima Çalışan - Eray Yağanak) Arkhe-Logos Felsefe Dergisi, (4), 2017.

NUSSBAUM, Martha C.: Poetic Justice, Beacon Press, 1995.

NUSSBAUM, Martha C.: Political Emotions: Why Love Matters for Justice, The Belknap Press of Harvard University Press, England 2013.

NUSSBAUM, Martha C.: Upheavals of Thought: The Intelligence of Emotions, Cambridge University Press, 2001

PILLSBURY, Samuel H.: “Emotional Justice: Moralizing the Passions of Criminal Punishment”, Cornell Law Review, 74 ,

1989 , https://pdfs.semanticscholar.org/433b/de6775a3bfe7a9dd3e7e1005f9b3421c2623.pdf (Erişim Tarihi: 21.10.2020)

PULCINI, Elena: “What Emotions Motivate Care?", Emotion Review, 9(1), January 2017, https://journals.sagepub.com/doi/pdf/10.1177/1754073915615429 (Erişim Tarihi: 23.10.2020).

UYGUR, Gülriz: Hukukta Adaletsizliği Görmek, Türkiye Felsefe Kurumu, Ankara 2013. 